\title{
Perioperative fluid therapy: a statement from the international Fluid Optimization Group
}

Lais Helena Camacho Navarro ${ }^{1 *}$, Joshua A Bloomstone ${ }^{2}$, Jose Otavio Costa Auler $\mathrm{Jr}^{3}$, Maxime Cannesson ${ }^{4}$, Giorgio Della Rocca ${ }^{5}$, Tong J Gan ${ }^{6}$, Michael Kinsky ${ }^{7}$, Sheldon Magder ${ }^{8}$, Timothy E Miller ${ }^{6}$, Monty Mythen', Azriel Perel ${ }^{10}$, Daniel A Reuter ${ }^{11}$, Michael R Pinsky ${ }^{12}$ and George Kramer $^{7}$

\begin{abstract}
Background: Perioperative fluid therapy remains a highly debated topic. Its purpose is to maintain or restore effective circulating blood volume during the immediate perioperative period. Maintaining effective circulating blood volume and pressure are key components of assuring adequate organ perfusion while avoiding the risks associated with either organ hypo- or hyperperfusion. Relative to perioperative fluid therapy, three inescapable conclusions exist: overhydration is bad, underhydration is bad, and what we assume about the fluid status of our patients may be incorrect. There is wide variability of practice, both between individuals and institutions. The aims of this paper are to clearly define the risks and benefits of fluid choices within the perioperative space, to describe current evidence-based methodologies for their administration, and ultimately to reduce the variability with which perioperative fluids are administered.
\end{abstract}

Methods: Based on the abovementioned acknowledgements, a group of 72 researchers, well known within the field of fluid resuscitation, were invited, via email, to attend a meeting that was held in Chicago in 2011 to discuss perioperative fluid therapy. From the 72 invitees, 14 researchers representing 7 countries attended, and thus, the international Fluid Optimization Group (FOG) came into existence. These researches, working collaboratively, have reviewed the data from 162 different fluid resuscitation papers including both operative and intensive care unit populations. This manuscript is the result of 3 years of evidence-based, discussions, analysis, and synthesis of the currently known risks and benefits of individual fluids and the best methods for administering them.

Results: The results of this review paper provide an overview of the components of an effective perioperative fluid administration plan and address both the physiologic principles and outcomes of fluid administration.

Conclusions: We recommend that both perioperative fluid choice and therapy be individualized. Patients should receive fluid therapy guided by predefined physiologic targets. Specifically, fluids should be administered when patients require augmentation of their perfusion and are also volume responsive. This paper provides a general approach to fluid therapy and practical recommendations.

Keywords: Fluid resuscitation, Perioperative fluids, Goal-directed fluid therapy, Fluid responsiveness

\footnotetext{
* Correspondence: laishnavarro@fmb.unesp.br

'Anesthesiology Department, Botucatu Medical School University of Sao

Paulo State - UNESP, District of Rubiao Junior s/n, Botucatu, Sao Paulo

18618-970, Brazil

Full list of author information is available at the end of the article
}

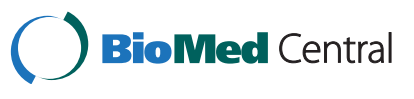

(c) 2015 Navarro et al.; licensee BioMed Central. This is an Open Access article distributed under the terms of the Creative Commons Attribution License (http://creativecommons.org/licenses/by/4.0), which permits unrestricted use, distribution, and reproduction in any medium, provided the original work is properly credited. The Creative Commons Public Domain Dedication waiver (http://creativecommons.org/publicdomain/zero/1.0/) applies to the data made available in this article, unless otherwise stated. 


\section{Background}

\section{Fluid therapy is important}

Major surgery is a considerable physiologic insult that can be associated with significant morbidity and mortality. The occurrence of one or more postoperative complications adversely effects both short-term and long-term survival and increases healthcare costs $[1,2]$. The prevention of postoperative morbidity is a key factor in providing high-quality, high-value health care.

Perioperative fluid management remains a highly debated topic. There is wide variability of practice, both between individuals and institutions. Perioperative morbidity is linked to the amount of intravenous fluid administered (fluid therapy) with both insufficient and, more commonly, excess fluid delivery leading to increased postoperative complications [3-5]. Currently taught and practiced methods of intraoperative volume management in which intravenous fluids are given based on a generalizable formula relying on body weight per unit time and modified by the perceived magnitude of surgical 'trauma' [6] are not supported by known physiologic principles. Fluid therapy should be considered when patients are both in need of enhanced blood flow and are fluid responsive.

Multiple studies have shown that approaching fluid therapy with the goal of hemodynamic stabilization can reduce complications after major surgery [7-9]. More compelling are several meta-analyses and quantitative reviews demonstrating the strength of these beneficial effects across patient groups and surgical procedures $[8,10]$. It is the purpose of this review to provide an overview of the components of an effective perioperative fluid administration plan.

\section{The physiologic principles of fluid support}

A patient's physiologic status in general and hemodynamic stability in particular define the need for cardiovascular support, including fluid therapy and use of vasoactive drugs (vasopressors, vasodilators) and inotropes. Specific hemodynamic goals include maintaining adequate blood volume and sustaining perfusion pressure so as to maintain cardiac output, tissue blood flow, and adequate oxygen delivery. Fluid therapy is often the first line of hemodynamic support because decreased effective circulating blood volume often accompanies induction of anesthesia and surgical trauma. However, fluid therapy only indirectly impacts cardiac and vascular function. Optimizing oxygen delivery and assuring the removal of metabolic bioproducts may require a combination of individualized fluid therapy, pharmacotherapy, and occasionally mechanical cardiovascular support.

Fluid infusions directly increase vascular volume, subsequently and usually improve global and regional perfusion and blood pressures if the heart is preload-responsive, and often improve oxygen delivery and tissue oxygenation.
However, these changes are profoundly influenced by the cardiac and peripheral vascular status [11]. Thus, the same fluid therapy can have profoundly different and occasionally opposite changes in cardiovascular state. For this reason, the blind infusion of fluids or the use of vasopressors without first understanding the patient's cardiovascular reserve is discouraged. Given these physiologic principles, hemodynamic optimization requires that the anesthesiologist consider three specific therapies for each patient: 1) fluid therapy for the correction of volume deficits associated with insufficient circulating blood volume and oxygen delivery, 2) vasopressors and vasodilators for arterial pressure and vascular tone, and 3) inotropic support when cardiac output remains inadequate despite optimization of volume (Figure 1).

Intravenous infusion of fluid directly expands plasma volume with transient or sustained effect that varies based on the colloid osmotic properties of the fluid, blood flow distribution, type and level of anesthesia, vascular endothelial integrity, and the physiologic state. The expansion of plasma volume causes the mean systemic pressure to increase, and, if greater than right atrial pressure, the pressure gradient for venous return will increase. If the right and left ventricle are volume responsive, then cardiac output will also increase. There is no easy means to measure plasma volume nor is there a defined means of how measured plasma volume could be used to achieve the physiologic goals of optimal pressure, flow, and oxygenation for the perioperative patient. Although one can estimate mean systemic filling pressure in appropriately instrumented patients, it is unclear if such measures will alter either therapy or outcome, because knowing plasma volume and even effective circulating blood volume only gives a partial picture of the determinants of cardiac output. Other critical factors include blood flow distribution, vasomotor tone, right ventricular function, and the level of positive-end expiratory pressure, which, individually and collectively, may alter cardiovascular responsiveness. Given the absence of easily obtainable regional measures of perfusion, the anesthesiologist may consider assessing global perfusion by measuring base deficit, lactate, and central and mixed venous oxygen saturation to clarify the impact of selected interventions.

Perioperative assessment of changes in blood volume is difficult and requires evaluation of several clinical and physiologic events that accompany major surgery. Standard hemodynamic monitoring devices fail to detect occult hypovolemia [12], which occurs frequently during surgery and contributes to inadequate tissue perfusion and the development of postoperative complications. Severely compromised patients may be identified by the presence of hypotension; however, not all patients in shock are hypotensive, and if one waits for hypotension, tissue hypoperfusion has already occurred [13]. For example, studies 


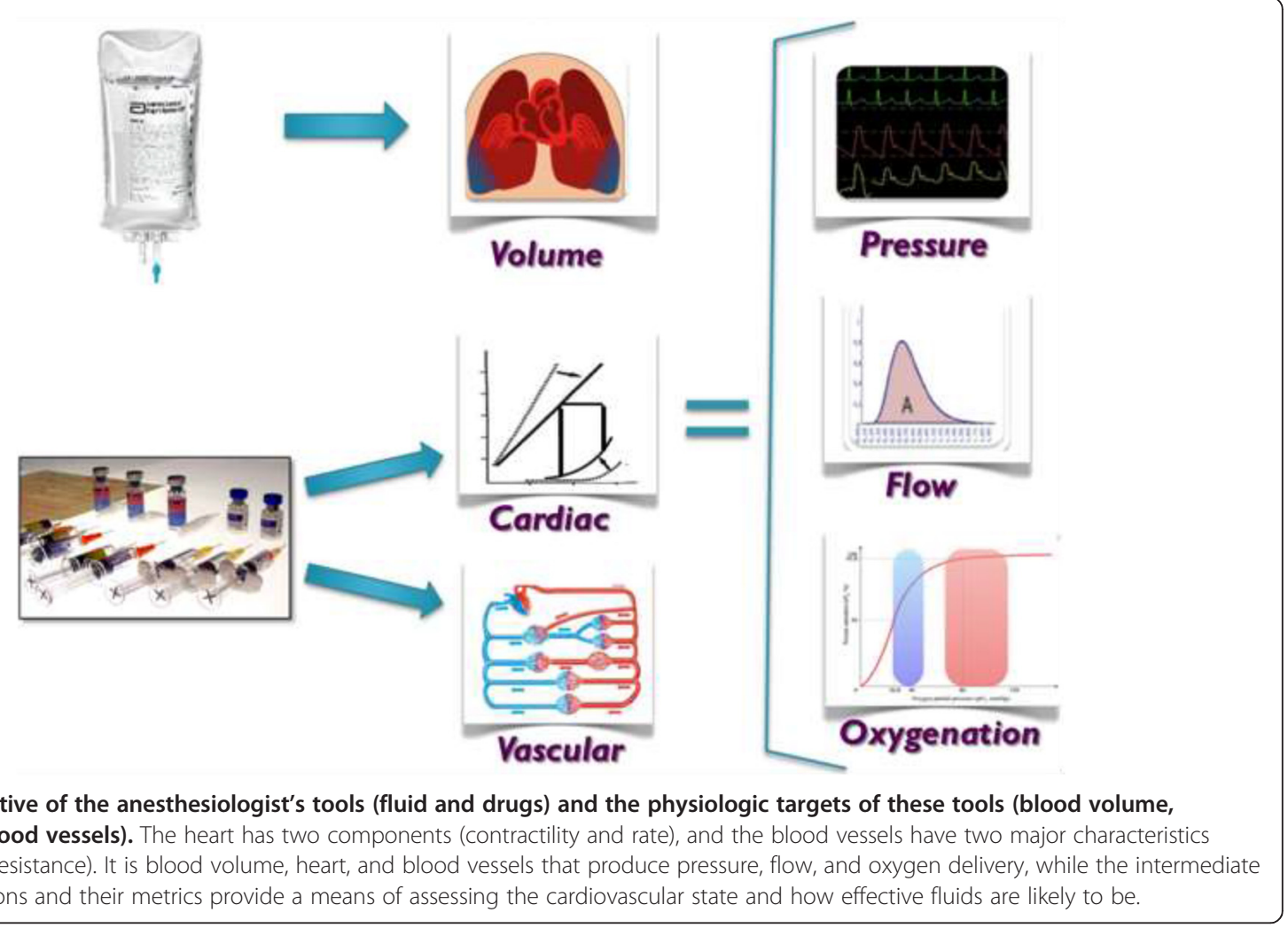

in healthy volunteers have shown that blood volume losses of $20 \%$ to $30 \%$ may occur with minimal change in blood pressure despite measurable impairment of tissue perfusion [14]. Moreover, hypotension should not serve as an automatic trigger for fluid administration since not all hypotensive events are due to hypovolemia.

Tachycardia is considered a classic sign of hypovolemia, but the assessment of intravascular volume based on heart rate lacks sensitivity and specificity [15] for a variety of reasons, not minimally because of the common use of beta-adrenergic receptor blocking agents in older surgical patients.

Perioperative hypovolemia is deleterious to organ function because normal adaptive mechanisms cause peripheral vasoconstriction to sustain blood flow to the heart and brain, causing ischemia to other organ and surgical tissues in need of blood flow for repair. For surgical patients, several factors including preoperative fasting, hypertonic bowel preparations, anesthetic agents, and positive pressure ventilation all contribute to reduced effective circulating blood volume. Anesthetized patients often present with a functional intravascular volume deficit [7]. On the other hand, large volumes of intravenous fluid may cause complications due to the formation of tissue edema. Liberal administration of fluid may impair pulmonary, cardiac, gastrointestinal, and renal function, contributing to postoperative complications and prolonged recovery [5,16-20].
Establishing what constitutes a restrictive or liberal amount of fluid from the literature is difficult because the absolute amounts of fluid administered vary substantially among trials making any conclusion difficult to implement in clinical practice [21]. Several studies have shown that the absolute amount of perioperative fluid administered may not be a major determinant of perioperative outcomes. Titration of fluid according to a hemodynamic goal is pivotal in improving perioperative outcomes [22]. In some studies, improved outcomes have been reported when set guidelines of 'restrictive' or 'limited' fluid therapy have been compared to standard care for GI surgeries [23-25] and in patients with pulmonary dysfunction [26,27]. These studies would seem to speak against individualized goal-directed therapy that is predicated upon optimizing intravascular volume. However, most certainly, the restrictive fluid studies and the goaldirected therapy (GDT) trials both make a strong case for having an a priori perioperative fluid plan. Taken as a whole, the success of both GDT and of some restrictive fluid strategies suggests that perioperative fluid planning must emphasize that fluid therapy be administered only with clear indication. Functional hemodynamic parameters offer unique information about fluid responsiveness, which my help detect fluid needs and avoid unnecessary fluid loading. Despite their limitations and confounding factors, this information may be crucial in guiding fluid 
therapy in surgical patients [28]. The exact set points and target values for the restoration and optimization of circulating volume, pressure, and perfusion must be determined for each patient.

\section{Perioperative goal-directed therapy impacts clinical outcomes}

Individual clinical trials and meta-analyses have shown that different fluid therapy regimens produce significantly different clinical outcomes and have resulted in considerable controversy as to the best approach. Table 1 lists trials of GDT trials applied within the perioperative space [23,29-59]. Most of these studies report higher rates of complications within the control groups. In high-risk surgical patients, perioperative fluid overload is associated with life-threatening complications, including pulmonary edema and death $[60,61]$. Interestingly, the application of specific GDT protocols has often been associated with increased delivery of fluids, especially colloids (Table 1), and in some studies less. Taken together, these data suggest that the benefit of fluid therapy is not primarily related to the volume infused, but rather how and when volume therapy is administered to a given patient.

The use of standardized fluid therapy protocols within the perioperative space is limited despite strong evidence of benefit. A survey by Cannesson et al. compared the fluid therapy practices of both American Society of Anesthesiologists (ASA) and European Society of Anesthesiology (ESA) members [62]. Standardized fluid therapy is sparsely practiced in the US with less than 6\% of ASA respondents having a facility-based written protocol while ESA members were five times more likely to have one.

Lack of standard criteria for fluid therapy results in significant clinical variability relative to the type and volume of fluid administered. This variability is linked to variable outcomes and makes it difficult to assess the effectiveness of different approaches [21,63]. A universal formula for an effective fluid management is fraught with difficulty because responses to fluid therapy vary widely between patients and not all patients benefit from fluids [64]. The complexity and individual variability of human physiology, presurgical morbidities, and the impact of different surgical procedures makes it easy to understand why a general, one-size-fits-all formula for fluid administration is unlikely to provide benefit.

\section{Methods}

Based on the abovementioned acknowledgements, a group of 72 researchers, well known within the field of fluid resuscitation, were invited, via email, to attend a meeting that was held in Chicago in 2011 to discuss perioperative fluid therapy. From the 72 invitees, 14 researchers representing 7 countries attended, and thus, the international Fluid Optimization Group (FOG) came into existence. These researches, working collaboratively, have reviewed the data from 162 different fluid resuscitation papers including both operative and intensive care unit populations.

\section{IRB}

There was no human research involved with this manuscript.

\section{Results}

This manuscript is the result of 3 years of evidence-based, discussions, analysis, and synthesis of the currently known risks and benefits of individual fluids and the best methods for administering them. The results of this review paper provide an overview of the components of an effective perioperative fluid administration plan and address both the physiologic principles and outcomes of fluid administration.

We present our evidence-based suggestions and individualized algorithms for a standardized approach to perioperative volume therapy for surgical patients. We propose specific recommendations for fluid administration which are organized into seven tenets as follows: 1) fluid responsiveness, dynamic indices, and the gray zone; 2) considerations of the composition of crystalloids and colloids; 3) evidence-based guidelines and individualized algorithms; 4) perioperative fluid plan; 5) goal-directed therapy; 6) the fluid challenge; and 7) maintenance fluids.

Recommendations are italicized.

\section{Discussion}

\section{Recommendations}

Fluid responsiveness, dynamic indices, and the gray zone

In patients who have cardiac rhythms with regular $R-R$ intervals and who are receiving controlled mechanical ventilation with tidal volumes between 8 and $10 \mathrm{ml} / \mathrm{kg}$, fluid responsiveness is most effectively assessed using dynamic indices. These should be measured in a uniform manner before and promptly after each fluid intervention [65-69]. Currently used dynamic indices include systolic pressure variation (SPV), pulse pressure variation (PPV), stroke volume variation (SVV), and plethysmographic waveform variation (PWV). The clinical utility of dynamic parameters is limited by many confounding factors that must be clearly understood by the clinician utilizing them [70].

The role of echocardiography, both transthoracic and transesophageal, can be critical when evaluating both fluid responsiveness and cardiac function. In addition, echocardiography is of particular use when assessing volume responsiveness in patients undergoing open chest surgery where the predictive ability of dynamic indices is also reduced [71].

Static parameters (for example, right or left ventricular diastolic diameter) derived from transesophagic echocardiography (TEE) monitoring are not useful in predicting 


\begin{tabular}{|c|c|c|c|c|c|c|c|}
\hline \multicolumn{4}{|l|}{ Protocols } & \multicolumn{2}{|c|}{$\begin{array}{l}\text { Fluids GDT } \\
\text { versus control }\end{array}$} & \multirow[b]{2}{*}{$\begin{array}{l}\text { Outcomes GDT versus } \\
\text { control }\end{array}$} & \multirow[b]{2}{*}{ Reference } \\
\hline Population & GDT endpoints & GDT therapy & Control protocol & Crystalloids & Colloids & & \\
\hline \multirow[t]{2}{*}{$\begin{array}{l}\text { Elective cardiac } \\
\text { surgery }\end{array}$} & $\begin{array}{l}\Delta \mathrm{SV}<10 \% \text { (esophageal } \\
\text { Doppler) }\end{array}$ & \multirow[t]{2}{*}{ Bolus $200 \mathrm{ml}$ colloid } & \multirow[t]{2}{*}{ Standard of care } & \multirow[t]{2}{*}{ Less } & \multirow[t]{2}{*}{ More } & \multirow{2}{*}{$\begin{array}{l}\text { Reduction of gut mucosal } \\
\text { hypoperfusion, less } \\
\text { postoperative } \\
\text { complications, shorter ICU } \\
\text { stay, shorter HLOS }\end{array}$} & \multirow[t]{2}{*}{ Mythen and Webb [29] } \\
\hline & $\Delta \mathrm{CVP}<3 \mathrm{mmHg}$ & & & & & & \\
\hline $\begin{array}{l}\text { Proximal femoral } \\
\text { fracture repair }\end{array}$ & $\begin{array}{l}\text { FTc }>400 \text { ms, } \Delta S V<10 \% \\
\text { (esophageal Doppler) }\end{array}$ & Bolus $3 \mathrm{ml} / \mathrm{kg}$ colloid & Standard of care & Similar & More & Shorter HLOS & Sinclair et al. [30] \\
\hline $\begin{array}{l}\text { Transthoracic } \\
\text { esophagectomy }\end{array}$ & $\mathrm{CVP}<5 \mathrm{mmHg}$ & Restrictive regimen & Standard of care & No data & No data & $\begin{array}{l}\text { Less postoperative } \\
\text { pulmonary complications }\end{array}$ & Kita et al. [31] \\
\hline \multirow[t]{2}{*}{ Major bowel surgery } & $\mathrm{FTc}>350 \mathrm{~ms}$ & \multirow[t]{2}{*}{ Bolus $3 \mathrm{ml} / \mathrm{kg}$ colloid } & \multirow[t]{2}{*}{ Standard of care } & \multirow[t]{2}{*}{ No data } & \multirow[t]{2}{*}{ More } & \multirow{2}{*}{$\begin{array}{l}\text { Less critical care } \\
\text { admission }\end{array}$} & \multirow[t]{2}{*}{ Conway et al. [32] } \\
\hline & $\Delta S V<10 \%$ (Doppler) & & & & & & \\
\hline \multirow[t]{2}{*}{ Major elective surgery } & $\mathrm{FTc}>350 \mathrm{~ms}$ & \multirow[t]{2}{*}{ Bolus $200 \mathrm{ml}$ colloid } & \multirow{2}{*}{$\begin{array}{l}\text { Standard of care (HR, } \\
\text { CVP, MAP, UO) }\end{array}$} & \multirow[t]{2}{*}{ Similar } & \multirow[t]{2}{*}{ More } & \multirow{2}{*}{$\begin{array}{l}\text { Less PONV, earlier oral } \\
\text { solid intake, shorter HLOS }\end{array}$} & \multirow[t]{2}{*}{ Gan et al. [33] } \\
\hline & $\Delta \mathrm{SV}<10 \%$ (Doppler) & & & & & & \\
\hline \multirow{3}{*}{$\begin{array}{l}\text { Proximal femoral } \\
\text { fracture repair }\end{array}$} & Doppler - FTc > 400 ms, & \multirow[t]{3}{*}{ Bolus $200 \mathrm{ml}$ colloid } & \multirow{3}{*}{$\begin{array}{l}\text { Standard of care } \\
\text { (without CVP or } \\
\text { Doppler) }\end{array}$} & \multirow[t]{3}{*}{ Similar } & \multirow[t]{3}{*}{ More } & \multirow{3}{*}{$\begin{array}{l}\text { Less intraoperative } \\
\text { hypotension, sooner } \\
\text { medically fit for discharge }\end{array}$} & \multirow[t]{3}{*}{ Venn et al. [34] } \\
\hline & $\Delta S \mathrm{SV}<10 \%$ & & & & & & \\
\hline & CVP $-\Delta C V P<5 m m H g$ & & & & & & \\
\hline $\begin{array}{l}\text { Elective colorectal } \\
\text { resection }\end{array}$ & $\begin{array}{l}\text { Maintaining preoperative } \\
\text { body weight }\end{array}$ & Restrictive regimen & Standard of care & Less & Similar & $\begin{array}{l}\text { Less postoperative } \\
\text { complications (tissue } \\
\text { healing, cardiopulmonary) }\end{array}$ & Brandstrup et al. [35] \\
\hline \multirow{4}{*}{$\begin{array}{l}\text { High-risk surgical } \\
\text { patients ( } \geq 60 \text { years } \\
\text { old) }\end{array}$} & $\begin{array}{l}\mathrm{DO}_{2}=550 \text { to } 600 \mathrm{ml} / \\
\mathrm{min} / \mathrm{m}^{2}\end{array}$ & $\begin{array}{l}\text { Fluids, inotropes, } \\
\text { vasodilators, }\end{array}$ & $\begin{array}{l}\text { Standard of care } \\
\text { (without PAC) }\end{array}$ & No data & No data & $\begin{array}{l}\text { More pulmonary } \\
\text { embolism }\end{array}$ & Sandham et al. [36] \\
\hline & $\mathrm{Cl}=3.5$ to $4.5 \mathrm{l} / \mathrm{min} / \mathrm{m}^{2}$ & & & & & & \\
\hline & $\mathrm{MAP}=70 \mathrm{mmHg}$ & & & & & & \\
\hline & $\mathrm{HR}<120 \mathrm{bpm}, \mathrm{Ht} \geq 27 \%$ & & & & & & \\
\hline Colorectal resection & $\Delta S V<10 \%$ (Doppler) & Bolus $250 \mathrm{ml}$ colloid & Routine monitoring & Similar & More & Shorter recovery of gut & Wakeling et al. [37] \\
\hline & $\Delta \mathrm{CVP}<3 \mathrm{mmHg}$ & & $\begin{array}{l}(\mathrm{CVP}=12 \text { to } \\
15 \mathrm{mmHg})\end{array}$ & & & $\begin{array}{l}\text { function, less morbidity, } \\
\text { shorter HLOS }\end{array}$ & \\
\hline Elective colorectal & $\mathrm{FTc}>350 \mathrm{~ms}$ & $7 \mathrm{ml} / \mathrm{kg}$ first bolus & Standard of care & Similar & Similar & Less inotrope use, earlier & Noblett et al. [38] \\
\hline & $\Delta \mathrm{SV}<10 \%$ (Doppler) & $\begin{array}{l}\text { collold, then bolus } \\
3 \mathrm{ml} / \mathrm{kg} \text { colloid }\end{array}$ & & & & $\begin{array}{l}\text { diet, less days to } \\
\text { medically fit, shorter } \\
\text { HLOS }\end{array}$ & \\
\hline $\begin{array}{l}\text { Low-risk patients } \\
\text { off-pump coronary } \\
\text { surgery }\end{array}$ & PAC & No data & Standard of care (CVP) & No data & No data & More use of inotropes & Resano et al. [39] \\
\hline $\begin{array}{l}\text { Major abdominal } \\
\text { surgery }\end{array}$ & $\mathrm{O}_{2} \mathrm{ER}<27 \%$ & $\begin{array}{l}\text { Colloid bolus, RBC, } \\
\text { dobutamine }\end{array}$ & $\begin{array}{l}\text { Standard of care } \\
\text { (MAP, UO) }\end{array}$ & No data & No data & $\begin{array}{l}\text { Less organ failure, shorter } \\
\text { HLOS }\end{array}$ & Donati et al. [40] \\
\hline
\end{tabular}


Table 1 Trials of goal-directed therapy [23,29-59] (Continued)

\begin{tabular}{|c|c|c|c|c|c|c|c|}
\hline \multirow{3}{*}{$\begin{array}{l}\text { Cardiac bypass } \\
\text { surgery }\end{array}$} & $\mathrm{GEDVI}=640 \mathrm{ml} / \mathrm{m}^{2}$ & \multirow{3}{*}{$\begin{array}{l}\text { Bolus } 500 \mathrm{ml}, \\
\text { vasopressors }\end{array}$} & \multirow{3}{*}{$\begin{array}{l}\text { Standard of care (CVP, } \\
\text { MAP, clinical } \\
\text { evaluation) }\end{array}$} & \multirow[t]{3}{*}{ Similar } & \multirow[t]{3}{*}{ More } & \multirow{3}{*}{$\begin{array}{l}\text { Shorter and reduced } \\
\text { need for vasopressors, } \\
\text { mechanical ventilation, } \\
\text { and ICU therapy }\end{array}$} & \multirow[t]{3}{*}{ Goepfert et al. [41] } \\
\hline & $\mathrm{Cl}>2.5 \mathrm{l} / \mathrm{min} / \mathrm{m}^{2}$ & & & & & & \\
\hline & $\mathrm{MAP}=70 \mathrm{mmHg}$ & & & & & & \\
\hline High-risk surgery & $\Delta \mathrm{PP}<10 \%$ & Bolus colloid & Standard of care & Similar & More & $\begin{array}{l}\text { Less postoperative } \\
\text { complications, shorter } \\
\text { time of mechanical } \\
\text { ventilation, ICU stay and } \\
\text { HLOS }\end{array}$ & Lopes et al. [42] \\
\hline \multirow[t]{4}{*}{$\begin{array}{l}\text { Moderate to high-risk } \\
\text { cardiac surgery }\end{array}$} & $\begin{array}{l}\mathrm{DO}_{2}=450 \text { to } 600 \mathrm{ml} / \\
\mathrm{min} / \mathrm{m}^{2}\end{array}$ & \multirow[t]{4}{*}{ Bolus $100 \mathrm{ml}$ colloid } & $\mathrm{CVP}=6$ to $8 \mathrm{mmHg}$ & \multirow[t]{4}{*}{ Similar } & \multirow[t]{4}{*}{ More } & \multirow{4}{*}{$\begin{array}{l}\text { Lower number of } \\
\text { adjustments of inotropic } \\
\text { agents }\end{array}$} & \multirow[t]{4}{*}{ Kapoor et al. [43] } \\
\hline & $\mathrm{Cl}=2.5$ to $4.2 \mathrm{l} / \mathrm{min} / \mathrm{m}^{2}$ & & $\begin{array}{l}\text { MAP }=90 \text { to } \\
105 \mathrm{mmHg}\end{array}$ & & & & \\
\hline & $\mathrm{SVI}=30$ to $65 \mathrm{ml} / \mathrm{beat} / \mathrm{m}^{2}$ & & $\cup O>1 \mathrm{ml} / \mathrm{kg} / \mathrm{h}$ & & & & \\
\hline & $\mathrm{ScvO}_{2}>70 \%, \mathrm{SW}<10 \%$ & & & & & & \\
\hline \multirow{2}{*}{$\begin{array}{l}\text { Off-pump coronary } \\
\text { surgery }\end{array}$} & $|\mathrm{TBV}|>850 \mathrm{ml} / \mathrm{m}^{2}$ & \multirow[t]{2}{*}{ Bolus $500 \mathrm{ml}$ colloid } & \multirow{2}{*}{$\begin{array}{l}\text { Standard of care } \\
\text { (MAP, CVP, HR) }\end{array}$} & \multirow[t]{2}{*}{ Similar } & \multirow[t]{2}{*}{ More } & \multirow[t]{2}{*}{ Shorter HLOS } & \multirow[t]{2}{*}{ Smetkin et al. [44] } \\
\hline & $\mathrm{ScvO}_{2}>60 \%$ & & & & & & \\
\hline \multirow{3}{*}{$\begin{array}{l}\text { Laparoscopic } \\
\text { segmental colectomy }\end{array}$} & 2 GDT groups: & \multirow{3}{*}{$\begin{array}{l}\text { Bolus } 200 \mathrm{ml} \text { colloid } \\
\text { or } 300 \mathrm{ml} \text { crystalloid }\end{array}$} & \multirow[t]{3}{*}{ Standard of care } & \multirow{3}{*}{$\begin{array}{l}\text { More (GDT } \\
\text { crystalloid) }\end{array}$} & \multirow{3}{*}{$\begin{array}{l}\text { More (GDT } \\
\text { colloid) }\end{array}$} & \multirow{3}{*}{$\begin{array}{l}\text { More postoperative } \\
\text { complications on group } \\
\text { GDT colloid }\end{array}$} & \multirow[t]{3}{*}{ Senagore et al. [45] } \\
\hline & $\Delta \mathrm{SV}<10 \%$ & & & & & & \\
\hline & Crystalloids versus colloids & & & & & & \\
\hline $\begin{array}{l}\text { Major abdominal } \\
\text { surgery }\end{array}$ & $P V I<13 \%$ & $\begin{array}{l}\text { Bolus } 250 \mathrm{ml} \text { colloid } \\
\text { (norepinephrine to } \\
\text { MAP }>65 \mathrm{mmHg} \text { ) }\end{array}$ & $\begin{array}{l}\text { Standard of care } \\
\text { (MAP, CVP) }\end{array}$ & Less & Similar & Lower lactate levels & Forget et al. [46] \\
\hline $\begin{array}{l}\text { Elective surgery for } \mathrm{Gl} \\
\text { malignancy }\end{array}$ & $\begin{array}{l}\text { Serum lactate }< \\
1.6 \mathrm{mmol} / \mathrm{l}\end{array}$ & $\begin{array}{l}\text { Bolus } 250 \text { to } 1,000 \mathrm{ml} \\
\text { colloid (depending } \\
\text { serum lactate) }\end{array}$ & Restrictive regimen & Similar & Similar & $\begin{array}{l}\text { Less systemic } \\
\text { complications in patients } \\
\text { that need postoperative } \\
\text { supplementary fluids }\end{array}$ & Wenkui et al., [47] \\
\hline $\begin{array}{l}\text { Major abdominal } \\
\text { surgery }\end{array}$ & $\begin{array}{l}\text { Peak aortic flow velocity } \\
<13 \% \text { (Doppler) }\end{array}$ & $\begin{array}{l}\text { Bolus } 250 \mathrm{ml} \text {, } \\
\text { vasopressors, } \\
\text { dobutamine, } \\
\text { restrictive crystalloids }\end{array}$ & $\begin{array}{l}\text { Standard of care } \\
\text { (12 } \mathrm{ml} / \mathrm{kg} / \mathrm{h} \\
\text { crystalloids) }\end{array}$ & $\begin{array}{l}\text { Less (patients } \\
\text { with complication) }\end{array}$ & $\begin{array}{l}\text { More (patients with } \\
\text { complication) }\end{array}$ & $\begin{array}{l}\text { More postoperative } \\
\text { complications }\end{array}$ & Futier et al. [48] \\
\hline $\begin{array}{l}\text { Peripheral artery } \\
\text { bypass grafting }\end{array}$ & $\mathrm{Cl}>2.5 \mathrm{l} / \mathrm{min} / \mathrm{m}$ & $\begin{array}{l}\text { Bolus } 250 \mathrm{ml} \text { colloid, } \\
\text { dobutamine }\end{array}$ & $\begin{array}{l}\text { Standard of care } \\
\text { (MAP, CVP) }\end{array}$ & No data & Similar & $\begin{array}{l}\text { No difference between } \\
\text { groups }\end{array}$ & $\begin{array}{l}\text { Van der Linden } \\
\text { et al. [49] }\end{array}$ \\
\hline \multirow{3}{*}{$\begin{array}{l}\text { Major abdominal } \\
\text { surgery }\end{array}$} & $\mathrm{Cl}>2.5 \mathrm{l} / \mathrm{min} / \mathrm{m}^{2}$ & \multirow{3}{*}{$\begin{array}{l}\text { Bolus } 500 \mathrm{ml} \\
\text { crystalloid, bolus } \\
250 \mathrm{ml} \text { colloid, } \\
\text { dobutamine, } \\
\text { norepinephrine }\end{array}$} & \multirow{3}{*}{$\begin{array}{l}\text { Standard of care } \\
\text { (MAP, CVP, UO) }\end{array}$} & \multirow[t]{3}{*}{ Less } & \multirow[t]{3}{*}{ More } & \multirow{3}{*}{$\begin{array}{l}\text { Less postoperative } \\
\text { complications, shorter } \\
\text { HLOS }\end{array}$} & \multirow[t]{3}{*}{ Mayer et al. [50] } \\
\hline & $\mathrm{SVI}>35 \mathrm{ml} /$ beat $/ \mathrm{m}^{2}$ & & & & & & \\
\hline & MAP $>65 \mathrm{mmHg}$ & & & & & & \\
\hline Elective intra- & $S W<10 \%$ & Bolus $3 \mathrm{ml} / \mathrm{kg}$ colloid, & Standard of care & Similar & More & Better intraoperative & Benes et al. [51] \\
\hline $\begin{array}{l}\text { abdominal surgery in } \\
\text { high-risk patients }\end{array}$ & $\mathrm{Cl}>2.5 \mathrm{l} / \mathrm{min} / \mathrm{m}^{2}$ & & $\begin{array}{l}\text { (IVAP > 65 mmHg, } 100 \mathrm{bpm}, \mathrm{CVP}=8 \\
\text { to } 15 \mathrm{mmHg}, \cup O> \\
0.5 \mathrm{ml} / \mathrm{kg} / \mathrm{h})\end{array}$ & & & $\begin{array}{l}\text { hemodynamic stability, } \\
\text { lower serum lactate, less } \\
\text { postoperative } \\
\text { complications }\end{array}$ & \\
\hline
\end{tabular}


Table 1 Trials of goal-directed therapy [23,29-59] (Continued)

\begin{tabular}{|c|c|c|c|c|c|c|c|}
\hline $\begin{array}{l}\text { Elective total hip } \\
\text { replacement }\end{array}$ & $\begin{array}{l}\mathrm{DO}_{2}>600 \mathrm{ml} / \mathrm{min} / \mathrm{m}^{2} \\
\Delta \mathrm{SV}<10 \%, \mathrm{Hb}>10 \mathrm{~g} / \mathrm{dl}\end{array}$ & $\begin{array}{l}\text { Bolus } 250 \mathrm{ml} \text { colloid, } \\
\text { dobutamine, RBC }\end{array}$ & $\begin{array}{l}\text { Standard of care } \\
\text { (MAP) }\end{array}$ & More & More & $\begin{array}{l}\text { Less postoperative } \\
\text { complications, } \\
\text { (hypotension, } \\
\text { cardiovascular) }\end{array}$ & Cecconi et al. [52] \\
\hline $\begin{array}{l}\text { Elective colorectal } \\
\text { surgery }\end{array}$ & $\Delta S V<10 \%$ & Bolus $200 \mathrm{ml}$ colloid & $\begin{array}{l}\text { Zero balance } \\
\text { intraoperative fluids } \\
(\mathrm{MAP}>60 \mathrm{mmHg})\end{array}$ & Similar & More & $\begin{array}{l}\text { No difference between } \\
\text { groups }\end{array}$ & Brandstrup et al. [23] \\
\hline \multirow{3}{*}{$\begin{array}{l}\text { Major abdominal } \\
\text { surgery (cirrhotic } \\
\text { patients) }\end{array}$} & 2 GDT groups: & \multirow{3}{*}{$\begin{array}{l}\text { Bolus } 250 \mathrm{ml} \mathrm{LR} \\
\text { followed by } 3 \mathrm{ml} / \mathrm{kg} \\
\text { colloid }\end{array}$} & \multirow[t]{3}{*}{ Same for both groups } & \multirow[t]{3}{*}{ Similar } & \multirow[t]{3}{*}{ Similar } & \multirow{3}{*}{$\begin{array}{l}\text { No difference between } \\
\text { groups }\end{array}$} & \multirow[t]{3}{*}{ Abdullah et al. [53] } \\
\hline & $P V \mid<13 \%$ & & & & & & \\
\hline & $\mathrm{FTc}>350 \mathrm{~ms}$ & & & & & & \\
\hline $\begin{array}{l}\text { Major colorectal } \\
\text { surgery }\end{array}$ & $\Delta \mathrm{SV}<10 \%$ & Bolus $200 \mathrm{ml}$ colloid & Standard of care & Similar & More & $\begin{array}{l}\text { More blood loss and } \\
\text { need for transfusion in } \\
\text { OR, longer HLOS }\end{array}$ & Challand et al. [54] \\
\hline \multirow{3}{*}{$\begin{array}{l}\text { Noncardiac major } \\
\text { surgery }\end{array}$} & $\mathrm{FTc}>300 \mathrm{~ms}, \Delta \mathrm{SV}<10 \%$ & \multirow[t]{3}{*}{ Bolus $200 \mathrm{ml}$ colloid } & \multirow{3}{*}{$\begin{array}{l}\text { Bolus } 200 \mathrm{ml} \\
\text { crystalloid }\end{array}$} & \multirow[t]{3}{*}{ Less } & \multirow[t]{3}{*}{ More } & \multirow{3}{*}{$\begin{array}{l}\text { Less transfusion of FFP, } \\
\text { better hemodynamic } \\
\text { stability }\end{array}$} & \multirow[t]{3}{*}{ Feldheiser et al. [55] } \\
\hline & $\mathrm{MAP}>70 \mathrm{mmHg}$ & & & & & & \\
\hline & $\mathrm{Cl}>2.5 \mathrm{l} / \mathrm{min} / \mathrm{m}^{2}$ & & & & & & \\
\hline \multirow[t]{2}{*}{ Elective colectomy } & $\mathrm{FTc}>400 \mathrm{~ms}$ & \multirow{2}{*}{$\begin{array}{l}7 \mathrm{ml} / \mathrm{kg} \text { first bolus } \\
\text { colloid, then bolus } \\
3 \mathrm{ml} / \mathrm{kg} \text { colloid }\end{array}$} & Restrictive regimen & \multirow[t]{2}{*}{ Similar } & \multirow[t]{2}{*}{ More } & \multirow{2}{*}{$\begin{array}{l}\text { No differences in } \\
\text { outcomes }\end{array}$} & \multirow[t]{2}{*}{ Srinivasa et al. [56] } \\
\hline & $\Delta S V<10 \%$ & & (HR, MAP, UO) & & & & \\
\hline $\begin{array}{l}\text { Cytoreductive surgery } \\
\text { (ovarian cancer) }\end{array}$ & $\Delta S V<10 \%$ & Bolus $200 \mathrm{ml}$ & $200 \mathrm{ml}$ crystalloid & Less & More & $\begin{array}{l}\text { Better hemodynamic } \\
\text { stability, less FFP } \\
\text { transfusion }\end{array}$ & Feldheiser et al. [57] \\
\hline \multirow{3}{*}{$\begin{array}{l}\text { Major abdominal } \\
\text { surgery }\end{array}$} & $\mathrm{Cl}>2.5 \mathrm{l} / \mathrm{min} / \mathrm{m}^{2}$ & \multirow{3}{*}{$\begin{array}{l}\text { Fluids, dobutamine, } \\
\text { vasopressors }\end{array}$} & \multirow[t]{3}{*}{ Standard of care } & \multirow[t]{3}{*}{ Similar } & \multirow[t]{3}{*}{ Similar } & \multirow{3}{*}{$\begin{array}{l}\text { Less postoperative } \\
\text { complications, lower } \\
\text { infection rate }\end{array}$} & \multirow[t]{3}{*}{ Salzwedel et al. [58] } \\
\hline & $P P V<10 \%$ & & & & & & \\
\hline & MAP $>65 \mathrm{mmHg}$ & & & & & & \\
\hline $\begin{array}{l}\text { Major abdominal } \\
\text { surgery }\end{array}$ & COSV & Bolus $250 \mathrm{ml}$ colloid & Standard of care (CVP) & Less & More & $\begin{array}{l}\text { No difference in } \\
\text { outcomes }\end{array}$ & Pearse et al. [59] \\
\hline
\end{tabular}


volume responsiveness [72]. On the other hand, echoderived dynamic indices such as delta IVC and delta SVC diameter during positive pressure ventilation have shown to be effective for evaluating fluid responsiveness [73]. As with all echocardiographic techniques, image acquisition and interpretation requires considerable education and experience. Furthermore, equipment expense still remains a considerable barrier to widespread implementation.

While dynamic indices are excellent for predicting volume responsiveness, measured changes in cardiac output $(\Delta \mathrm{CO})$ or stroke volume $(\Delta \mathrm{SV})$ may be required to assure the effectiveness of a fluid bolus [74,75]. Dynamic indices can be used to predict when fluid therapy could be administered and when its administration should be stopped. Bolus volume therapy should be discontinued when a patient reaches that point on their Frank-Starling curve where further volume therapy will not augment cardiac stroke volume (dynamic index $<10 \%, \Delta S V$ or $\Delta \mathrm{CO}<10 \%)$.

Dynamic indices have been repeatedly shown to accurately reflect fluid responsiveness and do so better than commonly used static hemodynamic parameters. These parameters have been validated and used to guide fluid therapy in a variety of surgical patients, including those undergoing major abdominal [42,50,68,76-78], cardiac [69,79-86], neurosurgical $[87,88]$, and vascular surgery [89]. Static measures such as central venous pressure (CVP) may be invaluable during patient care [90]; however, CVP is not useful as a predictor of volume responsiveness.

Dynamic parameters should be an integral part of GDT protocols for those patients in which they can be accurately measured. $\Delta C O$ or $\Delta S V$ can be used in the remaining patients. Not taking into account the status of fluid responsiveness when making fluid therapy decisions is bound to result in unjustified fluid administration even when GDT is being used. In addition, dynamic parameters may precede continuously measured $\mathrm{CO}$, heart rate, and blood pressure in alerting to the development of hypovolemia and may therefore trigger an early and justified fluid administration [91,92]. It is important to realize, however, that the presence of fluid responsiveness is not an absolute indication to give fluids. The decision to administer fluid therapy must be supported by proof of volume responsiveness, the need for hemodynamic improvement, and the lack of associated risk [93]. Fluid load per se is not always the correct therapy for hemodynamic instability.

The predictive ability of various dynamic indices has been compared in a number of studies. PPV had been found to be somewhat more accurate than the SPV and SVV $[79,94,95]$. However, it is difficult to determine a single cutoff point to predict fluid responsiveness. Cannesson et al. showed that, despite strong predictive value, there is a range of PPV values, named the gray zone (between 9\% and 13\%), for which fluid responsiveness cannot be reliably predicted in $25 \%$ of patients during general anesthesia [93]. Moreover, the gray zone limits may change according to the fluid management strategy to be applied [93]. Thus, when PPV enters the gray zone, uncertainty exists and clinicians should utilize other tools to assess fluid responsiveness. Furthermore, the range applied to PPV may not be applicable when SVV or other dynamic indices are used for determining volume responsiveness. The gray zone for each dynamic index requires its own definition [96].

The interaction between PPV and SVV (PPV/SVV) has also been studied as a measure of dynamic vascular compliance $[97,98]$. These combined parameters may be used to identify those hypotensive patients who have an underlying vasodilatory component to their hypotensive state and, thus, the need for vasopressor therapy [99].

Since pulse oximetry is a standard noninvasive intraoperative monitor, the respiratory variation in the plethysmographic waveform (PWV) is potentially the most commonly available dynamic parameter in mechanically ventilated anesthetized patients [100]. The major problem with the clinical use of PWV is the significant impact of vasoconstriction (for example, hypotension, hypothermia) on the plethysmographic waveform. However, an increase in the PWV may be the first sign of the development of a still-occult hypovolemia and should prompt the anesthesiologist to consider the immediate administration of fluids.

Limitations of dynamic indices Fluid responsiveness measures cannot be used in all patients and at all times in many patients. Dynamic indices have a high predictive value in determining fluid responsiveness; however, specific criteria must be met in order to use these indices to assess fluid responsiveness. Intraoperative motion, electrosurgical equipment, and physiologic artifact (noise) can interfere with the accurate interpretation of dynamic indices. Four primary limitations may exist in the use of dynamic indices. First, arrhythmias (for example, atrial fibrillation) preclude the use of SPV, PPV, SVV, and PWV to predict volume responsiveness, while inferior and superior vena cava variability remain accurate. The same limitation of SPV, PPV, SVV, and PWV is seen in subjects having varying levels of spontaneous inspiratory efforts. Again, inferior vena and superior vena cava diameter variability may remain predictive of volume responsiveness during spontaneous breathing. Second, if tidal volumes are $<8 \mathrm{ml} / \mathrm{kg}$, then the negative predictive value of SPV, PPV, SVV, and PWV is decreased whereas threshold values $>13 \%$ variation still retain their positive predictive value. Third, marked decreases in chest wall compliance will decrease the positive predictive value of all indices whereas intra-abdominal hypertension may mask hypovolemia but will not alter the volume responsiveness 
prediction value of these indices. Fourth, in the setting of acute cor pulmonale, with marked ventricular interdependence, one will see a paradoxical positive SPV, PPV, SVV, or PWV which will increase more with fluid resuscitation. Thus, when dynamic indices are utilized for guiding fluid therapy, some measure of the effectiveness of augmented perfusion should be considered.

Importantly, if these indices have values $>20 \%$, then the subject is clearly volume responsive. However, values from $9 \%$ to $13 \%$ may represent a 'gray zone' with less positive and negative predictive values and greater patient-topatient variability. In these cases and when any of the above limitations precludes the use of these parameters, one may consider performing a fluid challenge or passive leg raising (PLR) maneuver [101]. In contrast to a mechanical breath that normally reduces CO, the PLR causes an 'endogenous fluid challenge' which will increase $\mathrm{CO}$ in 'responders'. The PLR maneuver with a sensitivity of $89.4 \%$ and a specificity of $91.4 \%$ for predicting volume responsiveness is best coupled with minimally invasive cardiac output monitors that can track changes in stroke volume and cardiac output dynamically and in real time regardless of the mode of ventilation [102,103]. The execution of PLR, however, necessitates a major positional change, which generally makes it impractical for intraoperative use. However, there are instances in the operating room (OR) where postural changes may induce a hemodynamic response that may serve as a diagnostic maneuver of fluid responsiveness.

We recommend that dynamic parameters be used as an integral part of GDT protocols. The limitations of each dynamic index must be taken into consideration as well as the concept of a gray zone. Dynamic parameters neither provide a measure of fluid bolus effectiveness nor should they to be used as an indication to give fluids. The final decision to administer fluids must be supported by the apparent need for hemodynamic improvement, the presence of fluid responsiveness, and the lack of associated risk.

\section{Composition of fluid therapy: crystalloids and colloids}

There has been extensive research evaluating the risks and benefits of specific types of fluids and developing alternative solutions that restore effective circulatory volume and enhance microcirculatory flow. Despite all these efforts, the ideal resuscitation fluid or combination of fluids remains undefined.

There are three fluid categories - crystalloids, colloids, and blood. Each has its unique characteristics and role in fluid therapy. This discussion will focus on crystalloid and colloid therapy.

- Crystalloids are electrolyte solutions which are best used to replace extracellular volume losses from perspiration, respiration, and urine output. Although crystalloids increase vascular volume and may improve hemodynamics, the effectiveness is transient and less than colloid solutions. Crystalloids can be classified by their composition and osmolality. Normal saline (NS) is slightly hypertonic at $308 \mathrm{mOsm} / \mathrm{l}$, and lactated Ringer's (LR) is slightly hypotonic at $273 \mathrm{mOsm} / \mathrm{l}$ comparing to plasma osmolality. Plasmalyte is the most balanced isotonic electrolyte solution and has an osmolality of 294 mOsm (Table 2).

- Colloids are solutions of macromolecular solutes that exert a colloid osmotic pressure across the microvascular tissue barrier and retain fluid in the intravascular bed. Colloids efficiently increase vascular volume, preload, cardiac output, and tissue perfusion in volume responsive patients. Many of the GDT trials that have shown improved outcomes employ the use of iterative infusions (small volume boluses) of colloid (Table 1) [23,29-59]. Compared with the hemodynamic and volume-restoring effects of crystalloid therapy, equi-efficacious volumes of colloid are smaller; thus, colloid use may be considered an approach to limiting total volumes, which may contribute to better outcomes.

Comparison with the plasma composition. Commonly used intravenous fluids vary considerably in osmolality, ionic composition, and $\mathrm{pH}$. Crystalloid selection should be based upon individual patient need with clinical consideration of these components.

The choice of fluids is largely based on traditional beliefs, context of practice, location [104], and cost. For example, in comparing the use of colloid to crystalloid for treating hypovolemia, clinicians from the UK, China, and Australia rely primarily on colloid therapy (55\% to

Table 2 Commonly applied crystalloid solutions: osmolality, cationic, and anionic composition

\begin{tabular}{lllllllll}
\hline Fluid & Osmolality $(\mathbf{m O s m} / \mathbf{l})$ & $\mathbf{p H}$ & $\mathbf{N a}^{+}(\mathbf{m E q} / \mathbf{l})$ & $\mathbf{K}^{+}(\mathbf{m E q} / \mathbf{l})$ & $\mathbf{C a}^{++}(\mathbf{m E q} / \mathbf{l})$ & Lactate $(\mathbf{m E q l} / \mathbf{l})$ & $\mathbf{C l}^{-}(\mathbf{m E q} / \mathbf{l})$ & $\mathbf{A c e t a t e ~}_{(\mathbf{m E q} / \mathbf{l})}$ \\
\hline Plasma & 285 to 295 & 7.4 & 142 & 4 & 5 & 27 & 1 & 154 \\
0.9\% saline & 308 & 5.5 & 154 & & & & 109 \\
Lactate Ringer's & 273 & 6.5 & 130 & 5.4 & 2.7 & & 98 & 27 \\
Plasmalyte & 294 & 7.4 & 140 & 5 & & & 29 \\
\hline
\end{tabular}


$75 \%$ of time), whereas only $13 \%$ of clinicians in the US use colloid for treating hypovolemia [105].

Results of clinical trials comparing fluid resuscitation with colloids and crystalloids in different populations have been conflicting. Most recently, as highlighted in clinical trials and meta-analyses, the safety of using specific colloids (starches) for fluid resuscitation has been questioned $[106,107]$. Table 3 shows the main current concerns regarding specific crystalloids and colloids [108-114].

The CRISTAL trial compared the effects of fluid resuscitation with colloids versus crystalloids on mortality in patients admitted to the ICU with hypovolemic shock. There was no difference in 28-day mortality between patients resuscitated with crystalloids or colloids. However, the 90-day mortality was significantly reduced in patients treated with colloids [115]. On the other hand, in patients with severe sepsis and capillary leakage, the fluid-sparing effect of colloids appears to be smaller than anticipated $[112,113]$. However, balancing the CRISTAL trial, the recently completed ALBIOS trial comparing 20\% albumin and crystalloid versus crystalloid in 1,818 septic patients demonstrated that the colloid group had a higher mean arterial pressure during the first 7 days whereas there were no differences in the total amount of fluids administered between the two groups and both 28-day and 90-day mortality rates were similar. Thus, there is no compelling evidence that adding colloids to fluid resuscitation materially alters clinically relevant outcomes [116].

Given the evidence of harm and lack of significant clinical benefit in critically ill patients, when considering the administration of synthetic colloids, the anesthesiologist should first assess patient-specific risk. There is no evidence that the deleterious effects of starch-based colloids occur with albumin. The beneficial hemodynamic effects of colloid in GDT groups versus standard of care therapy suggest benefit of nonstarch colloids such as albumin. It should be noted that the deleterious effects of starches have largely been reported in ICU trials where starch therapy was used for multiple days. In contrast, the beneficial effects of perioperative GDT trials that included starchbased volume therapy were only of limited duration and thus exposure. For this reason, we cannot conclude that the deleterious effects of starches shown in the ICU population are generalizable to the limited use that occurs in the immediate surgical space. Serious thought to the individual surgical patient's co-morbidities, especially acute kidney injury, can inform the anesthesiologist of potential increased risk of starch-based colloid therapy.

A recent Cochrane meta-analyses has concluded, however, that there is no evidence from randomized clinical trials that resuscitation with colloids, instead of crystalloids, reduces the risk of death in patients with trauma, burns, or following surgery [117]. Common to all metaanalyses and systematic reviews, inclusion of studies whose interventions and patient characteristics are often insufficiently comparable and, therefore, the calculation of a summary effect measure may be questioned. The resuscitation regimen, the type of colloid or crystalloid, and the end points that guided resuscitation differed between trials. Further, the value of colloids when used as part of GDT may be apparent only in high-risk surgery patients.

Similar caution and approach should be applied to other synthetic colloids such as dextran and gelatin. Scant clinical evidence exists as to either benefit or harm regarding to the administration of other colloid solutions such as dextran or gelatin to surgical patients. Siting theoretical safety concerns, some authors posit caution for the routine use of these fluids in surgical patients [117]. It should not be assumed that results from fluid resuscitation trials in ICU populations apply to surgical patients. Properly powered, prospective trials comparing different fluids in defined patient populations undergoing specific surgical procedures are needed [118].

We recommend crystalloid solutions for routine surgery of short duration. However, in major surgery, the use of a goal-directed fluid regimen containing colloid and balanced-salt solutions is recommended. Though a black box warning for the use of starch solutions exists within the US, there is limited data relative to their harm in the perioperative space. Careful consideration should occur in patients with known renal dysfunction and/or sepsis prior to administering starch solutions.

Table 3 Main current concerns regarding the use of specific crystalloids and colloids

\begin{tabular}{lll}
\hline Solution & Concerns & Literature \\
\hline Normal saline & Hyperchloremic acidosis & $\begin{array}{l}\text { Hyperchloremia after noncardiac surgery is independently } \\
\text { associated with morbidity and mortality [108] }\end{array}$ \\
& Reduction of renal perfusion & May contribute to acute renal injury [109,110] \\
Starch solutions & $\begin{array}{l}\text { Acute kidney injury and increased requirement of renal } \\
\text { replacement therapy }\end{array}$ & Critically ill septic patients [111-114] \\
& Increased mortality & Critically ill septic patients [112,114] \\
& Increased need for PRBC transfusion & Critically ill septic patients [114]
\end{tabular}




\section{Evidence-based guidelines and individualized algorithms}

Disagreement about optimal perioperative fluid therapy is exacerbated by the lack of uniform definitions for standard, restrictive, and supplemental fluid delivery [21]. This, in turn, hinders comparisons of published studies [119]. Better definitions of the fluid regimen will help facility champions to develop local guidelines and algorithms.

Guidelines are general suggestions of care based on principles extracted from evidence-based findings and consensus. Algorithms are highly specific as to the variable (s) used, their target values, and their specific steps.

The difference between a guideline and an algorithm is important. Guidelines do not provide sufficient detail to reduce variation of care. Two anesthesiologists could strictly adhere to a guideline, but their specific fluid therapy delivered to an identical patient could be quite different. Even one of these individual anesthesiologist's practices for two identical patients could differ from 1 day to another. Improved outcomes, reduced readmissions, and reduced costs have resulted when quality improvement programs have been implemented to reduce variability [120,121]. The implementation of algorithms or detailed protocols into routine anesthetic care is far more important than adherence to guidelines when attempting to reduce clinical variation. Enhanced recovery after surgery (ERAS) protocols represent multidisciplinary perioperative care pathways that seem to be associated with significant reductions of the surgical stress response, complications, and hospital length of stay (HLOS) [122,123]. A recent clinical trial showed that the implementation of an ERAS protocol for colorectal surgery at a tertiary medical center was associated with a significant reduction of HLOS for both open and laparoscopic colorectal surgeries. The authors, however, were not able to show significant difference in the total medical costs for patients in the ERAS pathway versus the traditional care group [124]. Importantly, fluid therapy was only one of the 23 steps that were implemented within the study protocol. Unfortunately, we are unable to define the impact of this critical step as the study was not designed to do so. It is likely that some interventions are more important than others relative to reducing complications, readmissions, and total hospital costs, and some may be nonessential. Indeed, Loftus et al. demonstrated that significant reductions in complications and readmissions could be realized with the implementation of a simple twostep ERAS protocol focusing on early ambulation and alimentation following colorectal surgery [121].

Importantly, algorithms should not be fixed, they should allow for individualizing fluid therapy based on changing physiologic need and response to fluid and drug therapy. Algorithms can become very detailed and are likely to be best implemented with computerized decision support $[125,126]$. Both guidelines and algorithms can be displayed in flow chart format or computerized. Figure 2 provides an example of fluid therapy algorithm [58]. There will be many perioperative events that require deviation from algorithms. There is no substitute for medical training and expertise; however, deviation from any protocol should have a rational basis. Furthermore, nonadherence is often an opportunity to better understand and improve guidelines and algorithms.

Computerized decision support and implementation of closed-loop fluid administration has been described. Significant regulatory challenges exist before these systems can be introduced into clinical practice [127,128]. Recently, the first clinical use of a closed-loop fluid management system was reported [129]. With this approach, $91 \%$ of the physiologic targets were obtained. The authors suggest that the use of a closed-loop fluid management system may ease the implementation of algorithms, increase compliance with best practices, and relieve clinicians from time-intensive repetitive tasks [128].

We recommend the use of algorithms as part of the perioperative fluid plan. These should be available and easily accessible within all operating rooms. We encourage continued development, refinement, and testing of computerized decision support tools.

\section{The perioperative fluid plan}

The use of protocols for perioperative hemodynamic support which enhance tissue perfusion has been shown in multiple meta-analyses to reduce organ dysfunction, mortality, and HLOS [7,10,130,131]. These outcomes are especially evident when applied to the sickest patients [132]. A fundamental aspect in any perioperative protocol is the use of a fluid therapy plan that should be centered on physiological principles, evidence-based medicine, and local expertise. Given the absence of an internationally accepted fluid protocol or comprehensive fluid therapy, guidelines creating local standards become imperative. The anesthesiologist should have an individualized perioperative fluid optimization and hemodynamic monitoring plan for each surgical patient based upon the following:

1) Patient status (health, age, physiology, and co-morbidities);

2) Surgical risk (procedure, approach, and surgical expertise);

3) Selection of hemodynamic monitoring based upon patient and surgical risk as well as the anesthesiologists' clinical management needs (continuous blood pressure, cardiac performance, volume responsiveness, acid-base management, optimize oxygenation and ventilation, central venous and/or pulmonary artery pressures, central or mixed venous oxygenation). Figure 3 shows a rational approach to intraoperative monitoring. 
a

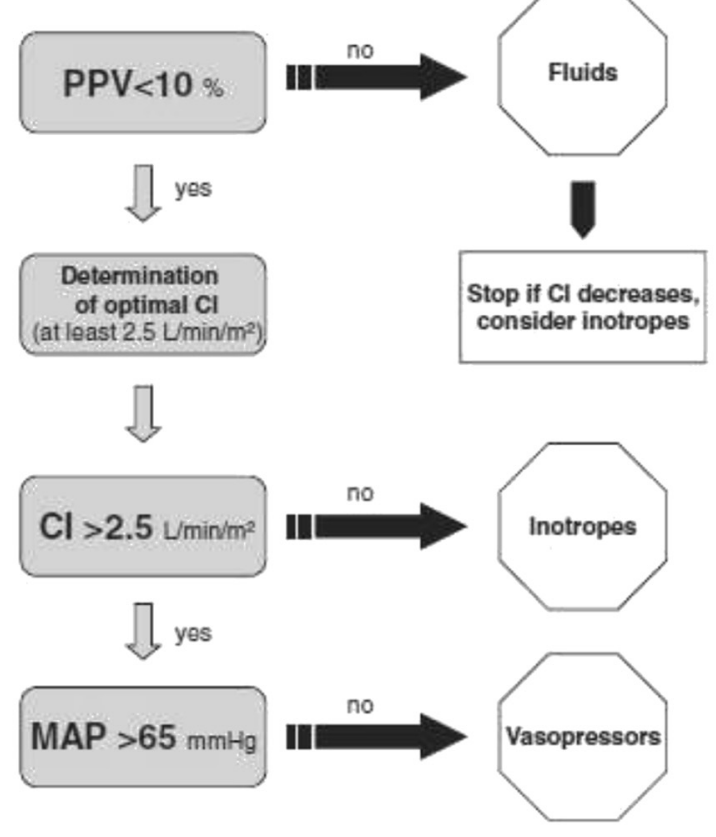

b

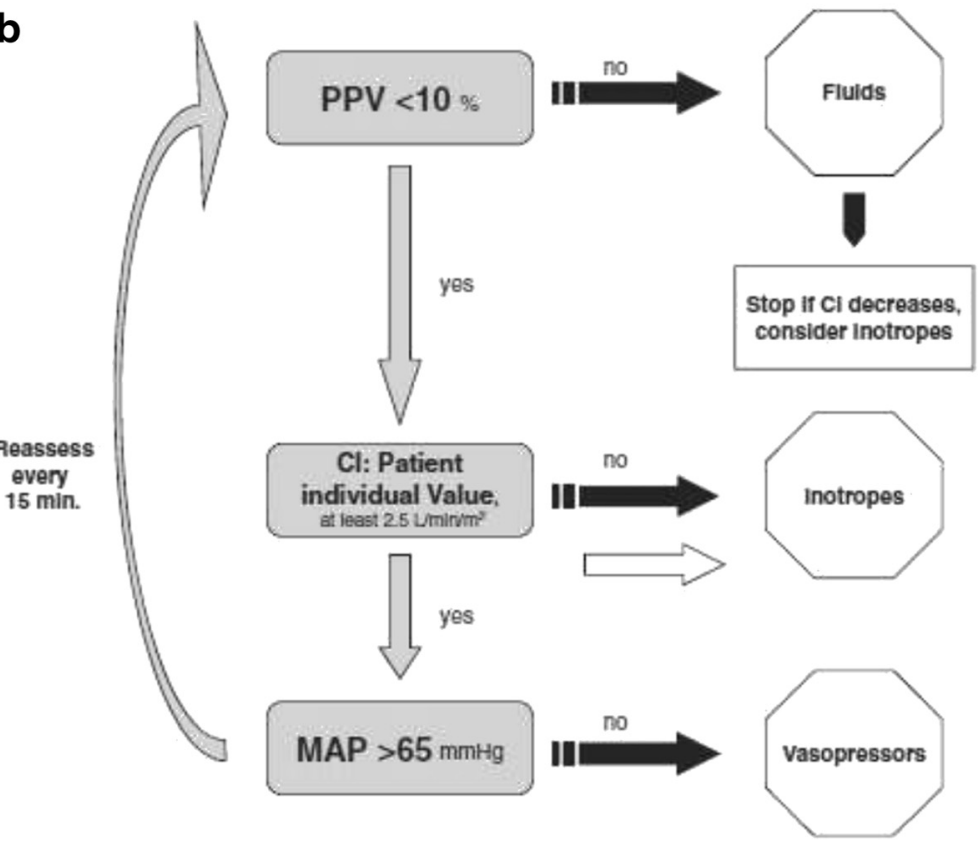

Figure 2 Goal-directed hemodynamic algorithm to guide intraoperative volume therapy in major abdominal surgeries: (a) initial assessment and treatment and (b) further intraoperative optimization [58] (used per BioMed Central's creative commons license). PPV, pulse pressure variation; $\mathrm{Cl}$, cardiac index; MAP, mean arterial pressure.

Hemodynamic monitoring Vincent et al. [133] proposed key principles regarding hemodynamic monitoring. Some of these principles are summarized in Table 4. In summary, the best choice for monitored variables depends on the type of patient, the question being asked, and the condition being managed or anticipated (Figure 3). It is crucial to understand that it is not the monitoring itself that can improve outcomes, but the changes in therapy guided by the data obtained [133,134]. Advantages of noninvasive or minimally invasive approaches are obvious. Further considerations of specific monitors are beyond the scope of this review.

In low-risk patients and low-risk surgery, the use of ASA standard monitors is often sufficient. However, if the associated risk or surgical procedure escalates, or if unexpected patient instability develops, additional expertise 


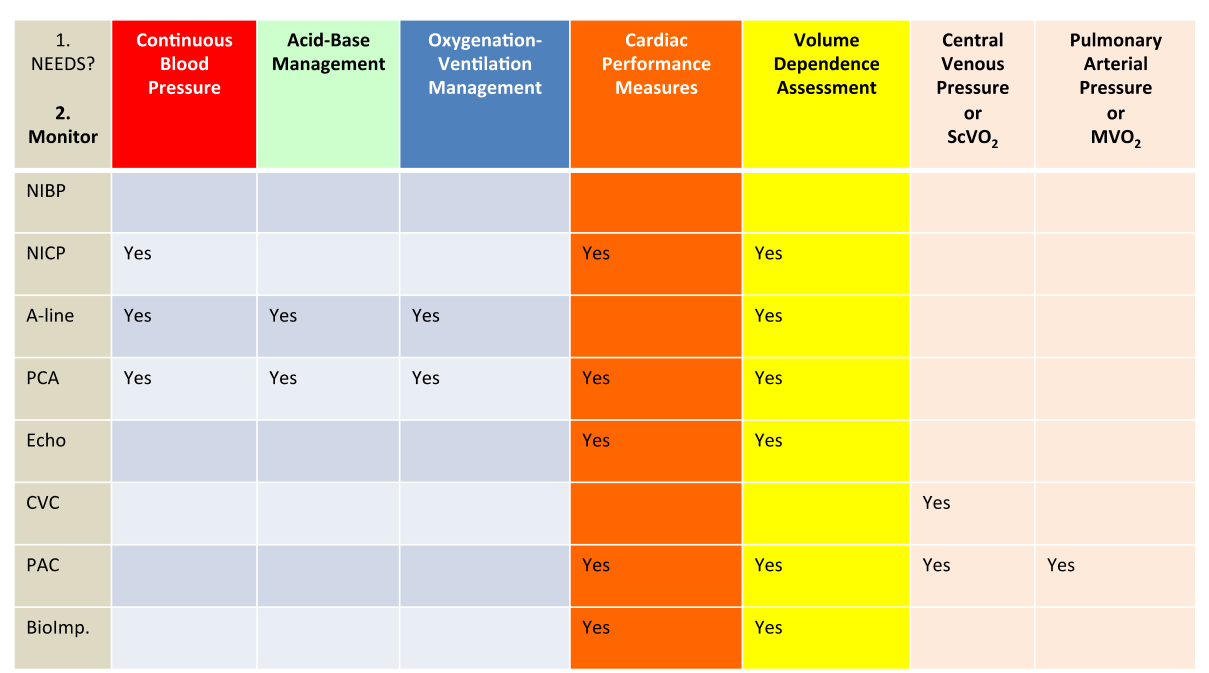

Figure 3 A rational approach to intraoperative monitoring. A useful approach for assessing the needed level of hemodynamic monitoring based on the patient status, surgical risk, and clinical management requirements (what are my management needs?). NIBP, noninvasive blood pressure; ECG, electrocardiogram; A-line, arterial catheterization; NICP, noninvasive continuous pressure; CVC, central venous catheter; ECHO, transthoracic or transesophageal echocardiography; PAC, pulmonary artery catheter; $\mathrm{ScVO}_{2}$, central venous oxygen saturation; $\mathrm{MVO}_{2}$, mixed venous oxygen saturation; PCA, pulse contour analysis; Biolmp, bioimpedance or bioreactance.

and/or monitoring are requisite. The advancement of monitoring is not without increased risk and cost; thus, these tools should only be applied when needed to provide a means to better detect and treat tissue mal-perfusion and potential organ dysfunction. Fluid therapy is a cornerstone for perioperative medicine, but clarity on when not to infuse fluids is as important as when to infuse. Hemodynamic and other advanced monitoring is often the best means to assess and assure the optimization of intravascular volume, pressure, perfusion, and oxygenation.

Invasive cardiovascular monitors can be considered in patients in whom tight hemodynamic control is needed to prevent rapid organ deterioration, for example, significant heart or brain disease and in high-risk surgical cases, for example, aortic and heart surgery. Indices from commonly used invasive monitors include intra-arterial pressure from an arterial catheter, right and left heart filling pressures, and central or mixed venous oxygenation saturations from central venous or pulmonary artery catheters, respectively.

There are several commercially available noninvasive or minimally invasive technologies that employ arterial pulse contour analysis, bioimpedance, or bioreactance and which provide continuous cardiac output, dynamic indices, and systemic vascular resistance. Finally, echocardiography, transthoracic and transesophageal (TEE), is becoming increasingly utilized in at risk patients. Mastering cardiac performance and volume assessment by TEE may improve currently available GDT algorithms.

We recommend that a perioperative fluid plan be developed by each department, facility, or health system and used by all anesthesiologists. Clinical needs, invasiveness, accuracy, and precision of available technologies should be considered when selecting monitoring devices.

Table 4 Principles of hemodynamic monitoring (Vincent et al.) [133]

\begin{tabular}{|c|c|}
\hline Principle & Rational \\
\hline $\begin{array}{l}\text { No hemodynamic monitoring technique can improve } \\
\text { outcome by itself }\end{array}$ & $\begin{array}{l}\text { If the data are interpreted or applied incorrectly the resultant change in management } \\
\text { will not improve patient outcome and may be deleterious }\end{array}$ \\
\hline Monitoring requirements may vary over time & $\begin{array}{l}\text { Optimal monitoring system depend on the individual patient, the problem already } \\
\text { present or potentially arising, and the devices and expertise available. Different } \\
\text { monitoring techniques can sometimes be used to complement each other. }\end{array}$ \\
\hline
\end{tabular}
that are applicable to all patients

Any variable on its own provides just one piece of a Variables should be combined and integrated large puzzle

Continuous measurements of hemodynamic variables_ Real time information and trends are useful on the perioperative settings is preferable

This table highlights a fundamental truth regarding hemodynamic monitoring and patient outcomes: Hemodynamic monitoring devices do not change patient outcomes unless coupled to treatments or treatment protocols which are known to improve outcome. 


\section{Goal-directed therapy}

Until recently, perioperative fluid replacement was guided primarily by estimates of known or anticipated fluid deficits and replacing these using fixed calculations for administration of intravenous fluid. Little outcome data exist that support the widespread use of fixed perioperative fluid regimens. Recent approaches have focused attention on the type of surgery being performed and the impact of the following outcomes: 1 ) the type of fluid being administered; 2) the timing of fluid administration; 3) the rate of fluid administration $[135,136]$; 4) the total amount of fluid administered; and 5) the best measures to both optimize and individualize perioperative fluid therapy [64].

Effective fluid therapy algorithms incorporate GDT. Table 1 lists trials of GDT for specific surgical procedures and the target goals and algorithms employed and their impact on outcomes. Algorithms should incorporate strategies and clinical pathways for patients who do not respond to fluid therapy ('nonresponders') and co-morbidities.

There are two overall challenges for fluid optimization as follows: 1) how to best identify hypovolemia and tissue hypoperfusion; and 2) how to best optimize vascular volume, cardiac filling, global, and regional perfusion and tissue oxygenation.

Identifying the need for hemodynamic support The most common parameters that are used to guide the need for hemodynamic support and perioperative fluids include clinical experience, urinary output, mean arterial pressure, and CVP $[62,137]$. Other variables that may be available include cardiac output, systemic vascular resistance, serum lactate, and central or mixed venous oxygen saturation. Peripheral pulses, skin temperature, appearance, and turgor are subjective measures that require significant clinical experience and acumen to be used effectively. The response of the $\mathrm{CO}$ to fluid administration depends on the preload status and on the contractile state of the heart, namely the slope of both the RV and LV function curve [138]. This explains why some hemodynamic variables, for example, central venous pressure, can fail to predict the response of the $\mathrm{CO}$ to fluid administration [65,79,139-141]. Only half (!) of critically ill and high-risk surgical patients, in whom fluid loading seems to be indicated, do indeed increase their $\mathrm{CO}$ in response to fluid loading ('responders'), while the other half ('nonresponders') can be loaded with fluids unnecessarily [72]. When making a decision about fluid administration, it is best to rely on the assessment of fluid responsiveness, that is, a measure of the change in CO in response to an increase in preload [142] as discussed below. The recently completed OPTIMISE trial when coupled with a meta-analysis of prior clinical trials demonstrated that using cardiac output targets to guide intraoperative fluid resuscitation decrease postoperative complications and reduce hospital length of stay [59].

Controversies within the GDT literature Although the goal-directed fluid therapy concept was first suggested more than 30 years ago [143], there remains no consensus about the most effective goals for fluid therapy or the most appropriated monitoring methods. As such, despite evidences demonstrating potential benefit of this technique in several disease states [144], GDT remains a well-accepted concept that has not yet translated to an established standard of care [145]. As exemplified in Table 1, directed comparison between studies is hampered by the large range of goals and methods for monitoring the inconsistency of study designs and the lack of common control groups [145]. Accordingly, there is an urgent need to address this research gap, providing high-quality evidence in support to different goals and methods of monitoring fluid therapy.

While the benefits of perioperative goal-directed fluid therapy have yet to be proven, the bulk of clinical research supports the implementation of a two-step GDT plan which is to begin immediately after induction of anesthesia. First, determine if the patient requires hemodynamic support or augmentation of cardiovascular function. Second, if the need is apparent and the patient is fluid responsive, fluid bolus therapy should be considered and guided by continual, and if available continuous, assessment of fluid responsiveness as described below.

\section{The fluid challenge}

A fluid challenge is one of the best tools that the anesthesiologist has for assessing fluid responsiveness. To test fluid responsiveness, a change in preload (fluid bolus) must be induced while monitoring the subsequent change in stroke volume, cardiac output, and dynamic indices [146].

The use of a fluid bolus provides two advantages as follows:

1) a means to assess the patient's response to fluid with changes in dynamic indices and static indices of volume, flow, and oxygenation;

2) a prompt increase in intravascular volume and usually a needed improvement in flow (cardiac output).

A fluid bolus is a provocative test of the circulation, similar to the use of a step function in engineering to define a system. The use of a 'test' that uses a small amount of fluid (bolus) to assess the volume responsiveness may reduce the risk of a too liberal fluid strategy and the possible consequences of fluid overload. These tools help to determine the requirements for additional fluid therapy avoiding the deleterious consequences of 
fluid overload through its small volume and targeted administration [147].

It is important to stress that the fluid challenge technique is a test of the cardiovascular system. It allows clinicians to assess whether a patient has enough preload reserve to increase stroke volume with further fluids. Fluid therapy should be considered after a positive response to a fluid challenge. In contrast to a single fluid challenge, fluids can also be infused in a controlled fashion based on an algorithm by repeating the fluid challenge as long as there is a positive response. This controlled approach is called stroke volume maximization and is the cornerstone of most goal-directed therapy protocols [38]. Thus, the only reason to perform a fluid challenge is to increase a patient's stroke volume; if this does not happen, further fluid administration is likely to be harmful [148].

A fluid challenge should comprise four separate orders: the type of fluid to be infused, the volume of fluid to be infused, the rate of the infusion, and the stopping rules if untoward effects are seen before the full amount of the bolus is infused. For rapid infusions of very small boluses of fluid (for example, $250 \mathrm{ml}$ crystalloid over 1 to $2 \mathrm{~min}$ ), stopping rules are probably not necessary. But if larger amounts of fluids or longer infusion times are used, clear stopping rules are important to prevent right heart failure or pulmonary edema.

Although no consensus is available for the type and exact dosing of fluid administration, boluses are best delivered at a rapid rate (5 to $10 \mathrm{~min}$ ) with prompt assessment of the physiologic response. The magnitude of this response helps to determine the effectiveness of the fluid challenge as well as the requirements for additional fluid therapy. Taken together, this approach avoids the deleterious consequences of fluid overload [147]. The peak and sustainment of improvement in dynamic and static variables after a fluid bolus is dependent on both the physiologic state and fluid composition. Moreover, sustainment of the response after bolus can be reduced in the presence of continuing hemorrhage.

Establishing volume status is complex, making accurate prediction of an increase in stroke volume upon fluid load challenging. However, under conditions of hypovolemia and inadequate perfusion, there is greater vascular retention of infused volume due to physiologic compensatory mechanisms that act to maintain normal volume, pressure, and perfusion. These compensatory mechanisms include the renal response to elevated vasopressin, angiotensin, and aldosterone; reduced capillary filtration due to reduced venous and capillary pressures; and decreased capillary hydraulic conductivity due to fluid composition and decreased levels of atrial natriuretic peptide (ANP) $[149,150]$. The use of a limited selection of specific volumes and delivered at set rate(s) of infusion provides a standardized test for volume responsiveness and a better means for the comparative assessment of changes in volume responsiveness.

We recommend bolus therapy rather than continuous infusion when the goal is to improve pressure, perfusion, and oxygen delivery. Standardization of the fluid bolus relative to fluid composition, volume, infusion rate, and time to post bolus assessment should be implemented. The variables used for assessing the effectiveness of the fluid bolus should include appropriate changes in cardiac output or stroke volume.

\section{Maintenance fluids}

Traditional perioperative fluid administration is guided by estimates of both the preoperative fluid deficit and by ongoing sensible and insensible intraoperative fluid losses. The notion that all surgical patients are hypovolemic due to prolonged fasting, bowel preparation, and ongoing losses from perspiration and urinary output is unfounded. Preoperative volume status is typically unknown and should not be presumed to be either adequate or inadequate. Blood volume varies considerably between patients depending on gender, weight, and oxygen consumption [151-153]. Moreover, effective circulatory volume varies when patients are under anesthesia [154]. Furthermore, our understanding of fluid shifting has changed and the so-called 'third space' has mostly been abandoned [155]. Additionally, perioperative deficits and insensible losses are often overestimated. Almost 40 years ago, direct measurements of basal evaporation rate from skin, airway and large exposure of bowel showed that fluid loss is 0.5 to $1.0 \mathrm{ml} / \mathrm{kg} / \mathrm{h}$ during major abdominal surgery [156]. Despite this fact, many current textbooks and guidelines for perioperative fluid management in major abdominal surgery suggest large amounts of crystalloids ( 5 to $7 \mathrm{ml} / \mathrm{kg} / \mathrm{h}$ ) for maintenance of intraoperative circulating volume [6].

The majority of the patients present with a minor functional intravascular deficit before surgery (200 to $600 \mathrm{ml}$ ) that is unlikely to have clinical significance [7]. This may explain why prophylactic fluid boluses have no major effects on the incidence or severity of anesthesia-related hypotension [157]. Research has shown that fasting from solid food for $6 \mathrm{~h}$ and fluids for $2 \mathrm{~h}$ prior to surgery is safe and improves outcomes compared with longer fasting periods [122]. Moreover, mechanical bowel preparation before elective abdominal surgery has been strongly challenged. Indeed, current ERAS guidelines discourage bowel preparation routinely for colonic surgery [122].

In the clinical context of ambulatory surgery in lowrisk patients, a more liberal fluid strategy may be beneficial. Up to 20 to $30 \mathrm{ml} / \mathrm{kg} / \mathrm{h}$ of crystalloid infusion reduces postoperative dizziness, drowsiness, pain, nausea, vomiting, and hospital length of stay [158-160]. To the contrary, studies of patients undergoing major surgery may favor a more restrictive fluid regime $[17,24]$, 
particularly in lengthy surgical procedures $(>6 \mathrm{~h})$ where fluid overloading significantly increases interstitial edema [161]. Because microvascular permeability peaks at 3 to $4 \mathrm{~h}$ after surgical injury [162], lengthy procedures are thus associated with capillary leakage and enhanced edema formation.

We recommend that maintenance fluids be administered at a rate of 1 to $2 \mathrm{ml} / \mathrm{kg} / \mathrm{h}$ for patients undergoing procedures of longer duration or magnitude. Patients undergoing outpatient procedures may benefit from higher maintenance fluid rates.

\section{Conclusions}

Although perioperative fluid management remains a highly debated subject, data suggests that goal-directed fluid therapy with the objective of hemodynamic optimization can reduce complications after major surgery. Specific hemodynamic goals include maintaining adequate circulating volume, perfusion pressure, and oxygen delivery. Lack of standard criteria for perioperative fluid therapy results in significant clinical variability relative to its administration.

In summary, fluids should be treated as any other intravenous drug therapy, and thus, careful consideration of its timing and dose is mandatory. A perioperative fluid plan should be developed which is easily understood and used by all anesthesiologists within a group, facility, or healthcare system. Determining both the need for augmented perfusion and fluid responsiveness is fundamental when making fluid therapy decisions to avoid unjustified fluid administration. Balanced crystalloid solutions should be given for short duration/low-risk surgical patients. Procedures of higher complexity are best managed with a combination of crystalloid and colloid therapy. When considering the administration of starch containing solutions, the anesthesiologist should first assess patientspecific risk. Finally, we recommend the use of algorithms as part of the perioperative fluid plan.

\footnotetext{
Abbreviations

ASA: American Society of Anesthesiologists; Cl: cardiac index; CO: cardiac output; CVC: central venous catheter; CVP: central venous pressure; $\mathrm{DO}_{2}$ : oxygen delivery; ECHO: transthoracic or transesophageal echocardiography; ERAS: enhanced recovery after surgery; FFP: fresh frozen plasma; FOG: Fluid Optimization Group; FTc: corrected flow time; GDT: goal-directed therapy; GEDVl: global end-diastolic volume index; HLOS: hospital length of stay; HR: heart rate; ICU: intensive care unit; ITBVI: intrathoracic blood volume index; IVC: inferior venous cava; LR: lactate Ringer's; LV: left ventricle; MAP: mean arterial pressure; $\mathrm{MVO}_{2}$ : myocardial oxygen consumption; NS: normal saline; $\mathrm{O}_{2}$ ER: oxygen extraction rate; PAC: pulmonary artery catheter; PCA: pulse contour analysis; PLR: passive leg raising; PONV: postoperative nausea and vomit; PP: pulse pressure; PPV: pulse pressure variation; PRBC: packed red blood cells; PVI: pulse variability index; PWV: plethysmographic waveform variation; RV: right ventricle; $\mathrm{SCVO}_{2}$ : central venous oxygen saturation; SPV: systolic pressure variation; SV: stroke volume; SVC: superior venous cava; SVI: stroke volume index; SW: stroke volume variation; TEE: transesophagic echocardiography; UO: urinary output.
}

\section{Competing interests}

Joshua A. Bloomstone is on the Speakers Bureau of Edwards Lifesciences, Irvine, California, United States. Maxime Cannesson is the founder of Sironis and hold equity in this company. During the past 5 years, Maxime Cannesson has consulted and/or has prepared CME materials for Covidien, Draeger, Philips Medical System, Gauss Surgical, Edwards Lifesciences, Fresenius Kabi, Masimo Corp., and ConMed. MC has received research fundings from Edwards Lifesciences and Masimo Corp. to support clinical studies for which he acts as a principal investigator. TJ Gan is the principal investigator of the research funded by Pacira, Covidien, Fresenius, Purdue, AcelRx, Acacia, Cubist, and Premier and has received honorarium for speaking from Merck, Cadence. Monty Mythen is a professor at the UCL and a consultant at the UCLH. He is director of the Research and Development for UCLH and a resident PI at the Institute of Spots Exercise and Health. He has received honoraria for speaking, or consultation and, or travel expenses from Baxter, BBraun, Covidien, Edwards Life Sciences, Fresenius-Kabi, Hospira, and LiDCO. He is a National Clinical Advisor for the Department of Health Enhanced Recovery Partnership; Smiths Medical Professor of Anaesthesia and Critical Care UCL; Director of Medical Defence Technologies LLC ('Gastrostim' patented); and Co-Inventor of 'QUENCH' (pump) IP being exploited by UCL Business. Professor Mythen's institution has also received charitable donations and grants from Smiths Medical Endowment and Deltex Medical. Timothy E. Miller is the Principle Investigator in a research funded by Edwards Lifesciences. Consultant for Edwards Lifesciences, Cheetah Medical, and Hospira. Azriel Perel is a member of the Medical Advisory Board of Pulsion Medical Systems, Munich, Germany. Daniel A. Reuter is a consultant at the Pulsion Medical Systems, Massimo and received honoraria for speaking from Pulsion, Edwards, Fresenius Kabi, and BBraun. Michael R. Pinsky is a Member Scientific Advisory Board and LiDCO Ltd. senior scientific advisor and has received Edwards Lifesciences honoraria for lectures at national and international scientific meetings: Edwards Lifesciences, Pulsion Ltd, Cheetah Medical, LiDCO Ltd, and Masimo Inc. and has stock options from Cheetah Medical and LiDCO Ltd. George C. Kramer is Chief Science Officer of Arcos, Inc. and Resuscitation Solutions and holds equity positions in both companies. Lais Helena Camacho Navarro, Jose Otavio Costa Auler Junior, Giorgio Della Rocca, Michael Kinsky, and Sheldon Magder declare that they have no competing interests.

\section{Authors' contributions}

LHCN helped at all stages in the creation of this review document from inception, debates on content to be included and excluded, revising the drafts, and final proofreading. JAB, MRP, and GCK helped at all stages in the creation of this review document from inception, debates on content to be included and excluded, revising the drafts, and final proofreading. JOCA, MC, GDR, TJG, MK, SM, TEM, MM, AP, and DAR Jr participated in the literature search and in the draft of the manuscript. All authors read and approved the final version of the manuscript.

\section{Author details}

${ }^{1}$ Anesthesiology Department, Botucatu Medical School University of Sao Paulo State - UNESP, District of Rubiao Junior s/n, Botucatu, Sao Paulo 18618-970, Brazil. 2Valley Anesthesiology Consultants, Ltd., Department of Anesthesia and Perioperative Medicine, Banner Thunderbird Medical Center, Banner Health, Glendale 85306, AZ, USA. 'Laboratory of Anesthesiology LIM08, Medical School - University of São Paulo, São Paulo 05508-070, São Paulo, Brazil. ${ }^{4}$ Department of Anesthesiology \& Perioperative Care, University of California, Irvine 92697CA, USA. ${ }^{5}$ Department of Anesthesia and ICM, University of Udine, Udine 33100, Italy. ${ }^{6}$ Department of Anesthesiology, Duke University Medical School, Durham 27710, NC, USA. ${ }^{7}$ Resuscitation Research Laboratory, Department of Anesthesiology, University of Texas Medical Branch, Galveston 7755-0801, TX, USA. ${ }^{8}$ Medicine and Physiology, McGill University, Montreal H3A 0G4, QC, Canada. ' University College London Hospital, 235 Euston Road, Fitzrovia, London NW1 2BU, UK. ${ }^{10}$ Department of Anesthesiology and Intensive Care, Sheba Medical Center, Tel Aviv University, Aviv 52621, Israel. ${ }^{11}$ Center of Anesthesiology and Intensive Care Medicine, Hamburg Eppendorf University Medical Center, Hamburg 20246, Germany. ${ }^{12}$ Department of Critical Care Medicine, University of Pittsburgh, Pittsburgh 15213, PA, USA.

Received: 28 November 2014 Accepted: 13 March 2015

Published online: 10 April 2015 


\section{References}

1. Khuri SF, Henderson WG, DePalma RG, Mosca C, Healey NA, Kumbhani DJ. Determinants of long-term survival after major surgery and the adverse effect of postoperative complications. Ann Surg. 2005;242:326-41.

2. Dimick JB, Chen SL, Taheri PA, Henderson WG, Khuri SF, Campbell Jr DA. Hospital costs associated with surgical complications: a report from the private-sector National Surgical Quality Improvement Program. J Am Coll Surg. 2004;199:531-7.

3. Bellamy MC. Wet, dry or something else? Br J Anaesth. 2006;97:755-7.

4. Doherty M, Buggy DJ. Intraoperative fluids: how much is too much? Br J Anaesth. 2012;109:69-79.

5. Holte K, Sharrock NE, Kehlet H. Pathophysiology and clinical implications of perioperative fluid excess. Br J Anaesth. 2002;89:622-32.

6. Kaye AD, Riopelle JM. Intravascular fluid and electrolyte physiology. In: Miller's Anesthesia. 7th ed. Missouri: Churchill Livingstone; 2009. p. 1705-37.

7. Bundgaard-Nielsen M, Jorgensen CC, Secher NH, Kehlet H. Functional intravascular volume deficit in patients before surgery. Acta Anaesthesiol Scand. 2010;54:464-9.

8. Hamilton MA, Cecconi M, Rhodes A. A systematic review and meta-analysis on the use of preemptive hemodynamic intervention to improve postoperative outcomes in moderate and high-risk surgical patients. Anesth Analg. 2011;112:1392-402

9. Lees N, Hamilton M, Rhodes A. Clinical review: goal-directed therapy in high risk surgical patients. Crit Care. 2009;13:231.

10. Gurgel ST, Nascimento Jr P. Maintaining tissue perfusion in high-risk surgica patients: a systematic review of randomized clinical trials. Anesth Analg. 2011;112:1384-91.

11. Chawla LS, Ince C, Chappell D, Gan TJ, Kellum JA, Mythen M, et al. Vascular content, tone, integrity, and haemodynamics for guiding fluid therapy: a conceptual approach. Br J Anaesth. 2014;113:748-55.

12. Junghans T, Neuss $H$, Strohauer M, Raue W, Haase O, Schink T, et al. Hypovolemia after traditional preoperative care in patients undergoing colonic surgery is underrepresented in conventional hemodynamic monitoring. Int J Colorectal Dis. 2006;21:693-7.

13. Cocchi MN, Kimlin E, Walsh M, Donnino M. Identification and resuscitation of the trauma patient in shock. Emerg Med Clin N Am. 2007:25:623-42.

14. Hamilton-Davies C, Mythen M, Salmon J, Jacobson D, Shukla A, Webb AR. Comparison of commonly used clinical indicators of hypovolemia with gastrointestinal tonometry. Intensive Care Med. 1997;23:276-81.

15. Iregui MG, Prentice D, Sherman G, Schallom L, Sona C, Kollef MH. Physician's estimates of cardiac index and intravascular volume based on clinical assessment versus transesophageal Doppler measurements obtained by critical care nurses. Am J Crit Care. 2003;12:336-42.

16. Holte $\mathrm{K}$, Kehlet $\mathrm{H}$. Fluid therapy and surgical outcomes in elective surgery: a need for reassessment of fast-track surgery. J Am Coll Surg. 2006;202:971-89.

17. Brandstrup B. Fluid therapy for the surgical patient. Best Pract Res Clin Anaesthesiol. 2006;20:265-83.

18. Marjanovic G, Villain C, Juettner E, Zur Hausen A, Hoeppner J, Hopt UT, et al. Impact of different crystalloid volume regimes on intestinal anastomotic stability. Ann Surg. 2009;249:181-5.

19. Nessim C, Sidéris L, Turcotte S, Vafiadis P, Lapostole AC, Simard S, et al. The effect of fluid overload in the presence of an epidural on the strength of colonic anastomoses. J Surg Res. 2013;183:567-73.

20. Kulemann B, Timme S, Seifert G, Holzner PA, Glatz T, Sick O, et al. Intraoperative crystalloid overload leads to substantial inflammatory infiltration of intestinal anastomoses - a histomorphological analysis. Surgery. 2013;154:596-603.

21. Rahbari NN, Zimmermann JB, Schmidt T, Koch M, Weigand MA, Weitz J. Meta-analysis of standard, restrictive and supplemental fluid administration in colorectal surgery. Br J Surg. 2009;96:331-41.

22. Corcoran T, Rhodes JEJ, Clarke S, Myles PS, Ho KM. Perioperative fluid management strategies in major surgery: a stratified meta-analysis. Anesth Analg. 2012;114:640-51.

23. Brandstrup B, Svendsen PE, Rasmussen M, Belhage B, Rodt SÅ, Hansen B, et al. Which goal for fluid therapy during colorectal surgery is followed by the best outcome: near-maximal stroke volume or zero fluid balance? Br J Anaesth. 2012;109:191-9.

24. Nisanevich V, Felsenstein I, Almogy G, Weissman C, Einav S, Matot I. Effect of intraoperative fluid management on outcome after intraabdominal surgery. Anesthesiology. 2005;103:25-32.
25. Srinivasa S, Lemanu DP, Singh PP, Taylor MH, Hill AG. Systematic review and meta-analysis of oesophageal Doppler-guided fluid management in colorectal surgery. Br J Surg. 2013;100:1701-8.

26. National Heart, Lung, and Blood Institute Acute Respiratory Distress Syndrome (ARDS) Clinical Trials Network, Wiedemann HP, Wheeler AP, Bernard GR, Thompson BT, Hayden D, et al. Comparison of two fluid-management strategies in acute lung injury. N Engl J Med. 2006:354:2564-75

27. Wiedemann HP. A perspective on the fluids and catheters treatment trial (FACTT) fluid restriction is superior in acute lung injury and ARDS. Cleve Clin J Med. 2008;75:42-8.

28. Perel A, Habicher M, Sander M. Bench-to-bedside review: functional hemodynamics during surgery - should it be used for all high-risk cases? Crit Care. 2013;17:203.

29. Mythen MG, Webb AR. Perioperative plasma volume expansion reduces the incidence of gut mucosal hypoperfusion during cardiac surgery. Arch Surg. 1995;130:423-9.

30. Sinclair $\mathrm{S}$, James $\mathrm{S}$, Singer $\mathrm{M}$. Intraoperative intravascular volume optimization and length of hospital stay after repair of proximal femoral fracture: randomized controlled trial. BMJ. 1997;315:909-12.

31. Kita T, Mammoto T, Kishi Y. Fluid management and postoperative respiratory disturbances in patients with transthoracic esophagectomy for carcinoma. J Clin Anesth. 2002:14:252-6.

32. Conway DH, Mayall R, Abdul-Latif MS, Gilligan S, Tackaberry C. Randomised controlled trial investigating the influence of intravenous fluid titration using oesophageal Doppler monitoring during bowel surgery. Anaesthesia. 2002:57:845-9.

33. Gan TJ, Soppitt A, Maroof M, El Moalem H, Robertson KM, Moretti E, et al. Goal-directed intraoperative fluid administration reduces length of hospital stay after major surgery. Anesthesiology. 2002;97:820-6.

34. Venn R, Steele A, Richardson P, Poloniecki J, Grounds M, Newman P. Randomized controlled trial to investigate influence of the fluid challenge on duration of hospital stay and perioperative morbidity in patients with hip fractures. Br J Anaesth. 2002;88:65-71.

35. Brandstrup B, Tønnesen $H$, Beier-Holgersen R, Hjortsø E, Ørding H, Lindorff-Larsen $\mathrm{K}$, et al. Effects of intravenous fluid restriction on postoperative complications: comparison of two perioperative fluid regimens: a randomized assessor-blinded multicenter trial. Ann Surg. 2003;238:641-8.

36. Sandham JD, Hull RD, Brant RF, Knox L, Pineo GF, Doig CJ, et al. A randomized, controlled trial of the use of pulmonary-artery catheters in high-risk surgical patients. N Engl J Med. 2003;348:5-14.

37. Wakeling HG, McFall MR, Jenkins CS, Woods WG, Miles WF, Barclay GR, et al. Intraoperative oesophageal Doppler guided fluid management shortens postoperative hospital stay after major bowel surgery. Br J Anaesth. 2005;95:634-42

38. Noblett SE, Snowden CP, Shenton BK, Horgan AF. Randomized clinical trial assessing the effect of Doppler-optimized fluid management on outcome after elective colorectal resection. Br J Surg. 2006;93:1069-76.

39. Resano FG, Kapetanakis El, Hill PC, Haile E, Corso PJ. Clinical outcomes of low-risk patients undergoing beating-heart surgery with or without pulmonary artery catheterization. J Cardiothorac Vasc Anesth. 2006;20:300-6.

40. Donati A, Loggi S, Preiser JC, Orsetti G, Münch C, Gabbanelli V, et al. Goal-directed intraoperative therapy reduces morbidity and length of hospital stay in high-risk surgical patients. Chest. 2007;132:1817-24.

41. Goepfert MS, Reuter DA, Akyol D, Lamm P, Kilger E, Goetz AE. Goal-directed fluid management reduces vasopressor and catecholamine use in cardiac surgery patients. Intensive Care Med. 2007;33:96-103.

42. Lopes MR, Oliveira MA, Pereira VOS, Lemos IPB, Auler JOC, Michard F. Goal-directed fluid management based on pulse pressure variation monitoring during high-risk surgery: a pilot randomized controlled trial. Crit Care. 2007;11:R100

43. Kapoor PM, Kakani M, Chowdhury U, Choudhury M, Lakshmy KU. Early goal-directed therapy in moderate to high-risk cardiac surgery patients. Ann Card Anaesth. 2008;11:27-34.

44. Smetkin AA, Kirov MY, Kuzkov W, Lenkin Al, Eremeev AV, Slastilin WY, et al. Single transpulmonary thermodilution and continuous monitoring of central venous oxygen saturation during off-pump coronary surgery. Acta Anaesthesiol Scand. 2009;53:505-14.

45. Senagore AJ, Emery T, Luchtefeld M, Kim D, Dujovny N, Hoedema R. Fluid management for laparoscopic colectomy: a prospective, randomized assessment of goal-directed administration of balanced salt solution or 
hetastarch coupled with an enhanced recovery program. Dis Colon Rectum. 2009;52:1935-40

46. Forget $\mathrm{P}$, Lois F, de Kock M. Goal-directed fluid management based on the pulse oximeter-derived pleth variability index reduces lactate levels and improves fluid management. Anesth Analg. 2010;111:910-4

47. Wenkui Y, Ning L, Jianfeng G, Weiqin L, Shaogiu T, Zhihui T, et al. Restricted peri-operative fluid administration adjusted by serum lactate level improved outcome after major elective surgery for gastrointestinal malignancy. Surgery. 2010;147:542-52

48. Futier E, Robin E, Jabaudon M, Guerin R, Petit A, Bazin JE, et al. Central venous $\mathrm{O}_{2}$ saturation and venous-to-arterial $\mathrm{CO}_{2}$ difference as complementary tools for goal-directed therapy during high-risk surgery. Crit Care. 2010;14:R193.

49. Van der Linden PJ, Dierick A, Wilmin S, Bellens B, De Hert SG. A randomized controlled trial comparing an intraoperative goal-directed strategy with routine clinical practice in patients undergoing peripheral arterial surgery. Eur J Anaesthesiol. 2010;27:788-93.

50. Mayer J, Boldt J, Mengistu AM, Röhm KD, Suttner S. Goal-directed intraoperative therapy based on autocalibrated arterial pressure waveform analysis reduces hospital stay in high-risk surgical patients: a randomized, controlled trial. Crit Care. 2010;14:R18.

51. Benes J, Chytra I, Altmann P, Hluchy M, Kasal E, Svitak R, et al. Intraoperative fluid optimization using stroke volume variation in high risk surgical patients: results of prospective randomized study. Crit Care. 2010;14:R118

52. Cecconi M, Langiano N, Divella M, Costa MG, Rhodes A, Della Rocca G. Goal-directed haemodynamic therapy during elective total hip arthroplasty under regional anaesthesia. Crit Care. 2011;15:R132.

53. Abdullah MH, Hasanin AS, Mahmoud FM. Goal directed fluid optimization using pleth variability index versus corrected flow time in cirrhotic patients undergoing major abdominal surgeries. Egyp J Anaesth. 2012;28:23-8.

54. Challand C, Struthers R, Sneyd JR, Erasmus PD, Mellor N, Hosie KB, et al. Randomized controlled trial of intraoperative goal-directed fluid therapy in aerobically fit and unfit patients having major colorectal surgery. $\mathrm{Br} J$ Anaesth. 2012;108:53-62.

55. Feldheiser A, Conroy P, Bonomo T, Cox B, Ruiz Garces T, Spies C, et al. Development and feasibility study of an algorithm for intraoperative goal-directed haemodynamic management in noncardiac surgery. J Int Med Res. 2012;40:1227-41.

56. Srinivasa S, Taylor MH, Singh PP, Yu TC, Soop M, Hill AG. Randomized clinical trial of goal-directed fluid therapy within an enhanced recovery protocol for elective colectomy. Br J Surg. 2013;100:66-74.

57. Feldheiser A, Pavlova V, Bonomo T, Jones A, Fotopoulou C, Sehouli J, et al. Balanced crystalloid compared with balanced colloid solution using a goal-directed haemodynamic algorithm. Br J Anaesth. 2013;110:231-40.

58. Salzwedel C, Puig J, Carstens A, Bein B, Molnar Z, Kiss K, et al. Perioperative goal-directed hemodynamic therapy based on radial arterial pulse pressure variation and continuous cardiac index trending reduces postoperative complications after major abdominal surgery: a multi-center, prospective, randomized study. Crit Care. 2013;17:R191.

59. Pearse RM, Harrison DA, MacDonald N, Gillies MA, Blunt M, Ackland G, et al. Effect of a peri-operative, cardiac output-guided, hemodynamic therapy algorithm on outcomes following major gastrointestinal surgery: a randomized clinical trial and updated systematic review. JAMA. 2014;311:2181-90.

60. Arieff Al. Fatal postoperative pulmonary edema: pathogenesis and literature review. Chest. 1999;115:1371-7.

61. Callum KG, Carr NJ, Gray AJ, Hargraves CM, Hoile RW, Ingram GS, et al. The report of the national confidential enquiry into perioperative death. London: National Confidential Enquiry Into Perioperative Deaths; 1999.

62. Cannesson M, Pestel G, Ricks C, Hoeft A, Perel A. Hemodynamic monitoring and management in patients undergoing high risk surgery: a survey among North American and European anesthesiologists. Crit Care. 2011;15:R197.

63. James MF, Michell WL, Joubert IA, Nicol AJ, Navsaria PH, Gillespie RS. Resuscitation with hydroxyethyl starch improves renal function and lactate clearance in penetrating trauma in a randomized controlled study: the FIRST trial (Fluids in Resuscitation of Severe Trauma). Br J Anaesth. 2011;107:693-702.

64. Yeager MP, Spence BC. Perioperative fluid management: current consensus and controversies. Semin Dial. 2006;19:472-9.

65. Michard F, Teboul JL. Predicting fluid responsiveness in ICU patients: a critical analysis of the evidence. Chest. 2002;121:2000-8.

66. Michard $F$. Changes in arterial pressure during mechanical ventilation. Anesthesiology. 2005;103:419-28.
67. Hofer CK, Muller SM, Furrer L, Klaghofer R, Genoni M, Zollinger A. Stroke volume and pulse pressure variation for prediction of fluid responsiveness in patients undergoing off-pump coronary artery bypass grafting. Chest. 2005;128:848-54

68. Solus-Biguenet H, Fleyfel M, Tavernier B, Kipnis E, Onimus J, Robin E, et al. Non-invasive prediction of fluid responsiveness during major hepatic surgery. Br J Anaesth. 2006;97:808-16.

69. Auler Jr JO, Galas F, Hajjar L, Santos L, Carvalho T, Michard F. Online monitoring of pulse pressure variation to guide fluid therapy after cardiac surgery. Anesth Analg. 2008;106:1201-6.

70. Perel A, Pizov R, Cotev S. Respiratory variations in the arterial pressure during mechanical ventilation reflect volume status and fluid responsiveness. Intensive Care Med. 2014;40:798-807.

71. de Waal EE, Rex S, Kruitwagen CL, Kalkman CJ, Buhre WF. Dynamic preload indicators fail to predict fluid responsiveness in open-chest conditions. Crit Care Med. 2009;37:510-5.

72. Marik PE, Cavallazzi R, Vasu T, Hirani A. Dynamic changes in arteria waveform derived variables and fluid responsiveness in mechanically ventilated patients: a systematic review of the literature. Crit Care Med. 2009;37:2642-7.

73. Levitov A, Marik PE. Echocardiographic assessment of preload responsiveness in critically ill patients. Cardiol Res Pract. 2012;2012:819696.

74. Kehlet $\mathrm{H}$, Bundgaard-Nielsen M. Goal-directed perioperative fluid management. Anesthesiology. 2009;110:453-5.

75. Kinberger O, Arnberger M, Brandt S, Plock J, Sigurdsson GH, Kurz A, et al. Goal-directed colloid administration improves the microcirculation of healthy and perianastomotic colon. Anesthesiology. 2009;110:496-504.

76. Pizov R, Eden A, Bystritski D, Kalina E, Tamir A, Gelman S. Arterial and plethysmographic waveform analysis in anesthetized patients with hypovolemia. Anesthesiology. 2010;113:83-91.

77. Hood JA, Wilson RJT. Pleth variability index to predict fluid responsiveness in colorectal surgery. Anesth Analg. 2011;113:1058-63.

78. Kobayashi M, Koh M, Irinoda T, Meguro E, Hayakawa Y, Takagane A. Stroke volume variation as a predictor of intravascular volume depression and possible hypotension during the early postoperative period after esophagectomy. Ann Surg Oncol. 2009;16:1371-7.

79. Preisman S, Kogan S, Berkenstadt H, Perel A. Predicting fluid responsiveness in patients undergoing cardiac surgery: functional haemodynamic parameters including the Respiratory Systolic Variation Test and static preload indicators. Br J Anaesth. 2005;95:746-55.

80. Cannesson M, Desebbe O, Rosamel P, Delannoy B, Robin J, Bastien O, et al. Pleth variability index to monitor the respiratory variations in the pulse oximeter plethysmographic waveform amplitude and predict fluid responsiveness in the operating theatre. Br J Anaesth. 2008;101:200-6.

81. Belloni L, Pisano A, Natale A, Piccirillo MR, Piazza L, Ismeno G, et al. Assessment of fluid-responsiveness parameters for off-pump coronary artery bypass surgery: a comparison among LiDCO, transesophageal echocardiography, and pulmonary artery catheter. J Cardiothorac Vasc Anesth. 2008;22:243-8.

82. Reuter DA, Felbinger TW, Schmidt C, Kilger E, Goedje O, Lamm P, et al. Stroke volume variations for assessment of cardiac responsiveness to volume loading in mechanically ventilated patients after cardiac surgery. Intensive Care Med. 2002;28:392-8.

83. Reuter DA, Kirchner A, Felbinger TW, Weis FC, Kilger E, Lamm P, et al. Usefulness of left ventricular stroke volume variation to assess fluid responsiveness in patients with reduced cardiac function. Crit Care Med. 2003;31:1399-404.

84. Hofer CK, Senn A, Weibel L, Zollinger A. Assessment of stroke volume variation for prediction of fluid responsiveness using the modified FloTrac and PiCCOplus system. Crit Care. 2008;12:R82.

85. Cannesson M, Musard H, Desebbe O, Boucau C, Simon R, Hénaine R, et al. The ability of stroke volume variations obtained with Vigileo/FloTrac system to monitor fluid responsiveness in mechanically ventilated patients. Anesth Analg. 2009;108:513-7.

86. Wyffels PAH, Durnez PJ, Helderweirt J, Stockman WMA, De Kegel D. Ventilation-induced plethysmographic variations predict fluid responsiveness in ventilated postoperative cardiac surgery patients. Anesth Analg. 2007;105:448-52

87. Berkenstadt H, Margalit N, Hadani M, Friedman Z, Segal E, Villa Y, et al. Stroke volume variation as a predictor of fluid responsiveness in patients undergoing brain surgery. Anesth Analg. 2001;92:984-9. 
88. Deflandre E, Bonhomme V, Hans P. Delta down compared with delta pulse pressure as an indicator of volaemia during intracranial surgery. $\mathrm{Br} \mathrm{J}$ Anaesth. 2007;100:245-50.

89. Coriat P, Vrillon M, Perel A, Baron JF, Le Bret F, Saada M, et al. A comparison of systolic blood pressure variations and echocardiographic estimates of end-diastolic left ventricular size in patients after aortic surgery. Anesth Analg. 1994;78:46-53.

90. Magder S. How to use central venous pressure measurements. Curr Opin Crit Care. 2005;11:264-70

91. Kungys G, Rose DD, Fleming NW. Stroke volume variation during acute normovolemic hemodilution. Anesth Analg. 2009;109:1823-30.

92. Pizov R, Eden A, Bystritski D, Kalina E, Tamir A, Gelman S. Hypotension during gradual blood loss: waveform variables response and absence of tachycardia. Br J Anaesth. 2012;109:911-8.

93. Cannesson M, Le Manach Y, Hofer CK, Goarin JP, Lehot JJ, Vallet B, et al. Assessing the diagnostic accuracy of pulse pressure variations for the prediction of fluid responsiveness: a "gray zone" approach. Anesthesiology. 2011;115:231-41

94. Marik PE, Cavalazzi R, Vasu T. Stroke volume variations and fluid responsiveness. Crit Care Med. 2009;37:26-42. 7.

95. Michard F, Boussat S, Chemla D, Anguel N, Mercat A, Lecarpentier Y, et al. Relation between respiratory changes in arterial pulse pressure and fluid responsiveness in septic patients with acute circulatory failure. Am J Respir Crit Care Med. 2000;162:134-8.

96. Bloomstone J, Raghunathan K, McGee WT. Why the gray zone may shift within the fog. Anesthesiology. 2012;116:733-43.

97. Hadian M, Severyn DA, Pinsky MR. The effects of vasoactive drugs on pulse pressure and stroke volume variation in postoperative ventilated patients. J Crit Care. 2011:26:328.

98. Monge Garcia Ml, Gil Cano A, Garcia Romero M. Dynamic arterial elastance to predict arterial pressure response to volume loading in preloaddependent patients. Crit Care. 2011;15:R15.

99. Pinsky MR. Heart lung interactions during mechanical ventilation. Curr Opin Crit Care. 2012;18:256-60

100. Maguire S, Rinehart J, Vakharia S, Cannesson M. Respiratory variation in pulse pressure and plethysmographic waveforms. Anesth Analg. 2011;112:94-6.

101. Guerin L, Monnet X, Teboul JL. Monitoring volume and fluid responsiveness: from static to dynamic indicators. Best Pract Res Clin Anaesthesiol. 2013;27:177-85

102. Marik PE, Lemson J. Fluid responsiveness: an evolution of our understanding. Br J Anaesth. 2014;112:620-2.

103. Cavallaro F, Sandroni C, Marano C, La Torre G, Mannocci A, De Waure C, et al. Diagnostic accuracy of passive leg raising for prediction of fluid responsiveness in adults: systematic review and meta-analysis of clinical studies. Intensive Care Med. 2010;36:1475-83.

104. Singer M. Management of fluid balance: a European perspective. Curr Opin Anesthesiol. 2012;25:96-101.

105. Finfer S, Liu B, Taylor C, Bellomo R, Billot L, Cook D, et al. Resuscitation fluid use in critically ill adults: an international cross-sectional study in 39 intensive care units. Crit Care. 2010;14:R185.

106. Estrada CA, Murugan R. Hydroxyethyl starch in severe sepsis: end of starch era? Crit Care. 2013;17:310

107. Phillips DP, Kaynar AM, Kellum JA, Gomez H. Crystalloids vs. colloids: KO at the twelfth round? Crit Care. 2013;17:319.

108. McCluskey SA, Karkouti K, Wijeysundera D, Minkovich L, Tait G, Beattie WS. Hyperchloremia after noncardiac surgery is independently associated with increased morbidity and mortality: a propensity-matched cohort study. Anesth Analg. 2013;117:412-21

109. Chowdhury AH, Cox EF, Francis ST, Lobo DN. A randomized, controlled, double-blind crossover study on the effects of $2-L$ infusions of $0.9 \%$ saline and plasma-lyte ${ }^{\oplus} 148$ on renal blood flow velocity and renal cortical tissue perfusion in healthy volunteers. Ann Surg 2012;256:18-24

110. Yunos NM, Bellomo R, Hegarty C, Story D, Ho L, Bailey M. Association between a chloride-liberal vs chloride-restrictive intravenous fluid administration strategy and kidney injury in critically ill adults. JAMA 2012;308:1566-72

111. Brunkhorst FM, Engel C, Bloos F, Meier-Hellmann A, Ragaller M, Weiler N, et al. Intensive insulin therapy and pentastarch resuscitation in severe sepsis. N Engl J Med. 2008;358:125-39.
112. Perner A, Haase N, Guttormsen AB, Tenhunen J, Klemenzson G, Åneman A, et al. Hydroxyethyl starch 130/0.42 versus Ringer's acetate in severe sepsis. N Engl J Med. 2012;367:124-34

113. Myburgh JA, Finfer S, Bellomo R, Billot L, Cass A, Gattas D, et al. Hydroxyethyl starch or saline for fluid resuscitation in intensive care. N Engl J Med. 2012;367:1901-11.

114. Haase N, Perner A, Hennings LI, Siegemund M, Lauridsen B, Wetterslev M, et al. Hydroxyethyl starch 130/0.38-0.45 versus crystalloid or albumin in patients with sepsis: systematic review with meta-analysis and trial sequential analysis. BMJ. 2013;346:f839.

115. Annane D, Siami S, Jaber S, Martin C, Elatrous S, Declère AD, et al. Effects of fluid resuscitation with colloids vs crystalloids on mortality in critically ill patients presenting with hypovolemic shock: the CRISTAL randomized trial. JAMA. 2013;310:1809-17.

116. Caironi P, Tognoni G, Masson S, Fumagalli R, Persenti A, Romero M, et al. Albumin replacement in patients with severe sepsis or septic shock. N Engl J Med. 2014. doi: 10.1056/NEJMoa1305727.

117. Lira A, Pinsky M. Choices in fluid type and volume during resuscitation: impact on patient outcomes. Ann Intensive Care. 2014;4:38.

118. Perel P, Roberts I, Kerk K. Colloids versus crystalloids for fluid resuscitation in critically ill patients. Cochrane Database Syst Rev. 2013;2:CD000567.

119. Chappell D, Jacob M, Hofmann-Kiefer K, Conzen P, Rehm M. A rational approach to perioperative fluid management. Anesthesiology. 2008;109:723-40.

120. James BC, Savitz LA. How Intermountain trimmed health care costs through robust quality improvement efforts. Health Aff. 2011;30:1185-91.

121. Loftus TJ, Stelton S, Efaw BW, Bloomstone J. A system-wide enhanced recovery program focusing on two key process steps reduces complications and readmissions in patients undergoing bowel surgery. J Healthcare Quality. 2014. doi:10.1111/jhq.12068.

122. Gustafsson UO, Scott MJ, Schwenk W, Demartines N, Roulin D, Francis N, et al. Guidelines for perioperative care in elective colonic surgery: Enhanced Recovery After Surgery (ERAS ${ }^{\circledR}$ ) Society recommendations. Clin Nutr. 2012;31:783-800.

123. Lassen K, Soop M, Nygren J, Cox PB, Hendry PO, Spies C, et al. Consensus review of optimal perioperative care in colorectal surgery: Enhanced Recovery After Surgery (ERAS) Group recommendations. Arch Surg. 2009;144:961-9.

124. Miller TE, Thacker JK, White WD, Mantyh C, Migaly J, Jin J, et al. Reduced length of hospital stay in colorectal surgery after implementation of an enhanced recovery protocol. Anesth Analg. 2014;118:1052-61.

125. Sucher JF, Moore FA, Todd SR, Sailors RM, McKinley BA. Computerized clinical decision support: a technology to implement and validate evidence based guidelines. J Trauma. 2008;64:520-37.

126. McKinley BA, Moore LJ, Sucher JF, Todd SR, Turner KL, Valdivia A, et al. Computer protocol facilitates evidence-based care of sepsis in the surgical intensive care unit. J Trauma. 2011;70:1153-66.

127. Kramer GC, Kinsky MP, Prough DS, Salinas J, Sondeen JL, Hazel-Scerbo ML, et al. Closed-loop control of fluid therapy for treatment of hypovolemia. J Trauma. 2008;64:S333-41.

128. Rinehart J, Liu N, Alexander B, Cannesson M. Closed loop systems in anesthesia: is there a potential for closed loop fluid management and hemodynamic optimization? Anesth Analg. 2012;114:130-43.

129. Rinehart J, Le Manach Y, Douiri H, Lee C, Lilot M, Le K, et al. First closed-loop goal directed fluid therapy during surgery: a pilot study. Ann Fr Anesth Reanim. 2014;33:e35-41.

130. Zargar-Shoshtari K, Hill AG. Optimization of perioperative care for colonic surgery: a review of the evidence. ANZ J Surg. 2008;78:13-23.

131. Giglio MT, Marucci M, Testini M, Brienza N. Goal-directed haemodynamic therapy and gastrointestinal complications in major surgery: a meta-analysis of randomized controlled trials. Br J Anaesth. 2009;103:637-46.

132. Cecconi M, Corredor C, Arulkumaran N, Abuella G, Ball J, Grounds RM, et al. Clinical review: goal-directed therapy-what is the evidence in surgical patients? The effect on different risk groups. Crit Care. 2013;17:209.

133. Vincent IL, Rhodes A, Perel A, Martin G, Della Rocca G, Vallet B, et al. Clinical review: update on hemodynamic monitoring - a consensus of 16. Crit Care. 2011;15:229.

134. Pinsky MR, Payen D. Functional hemodynamic monitoring. Crit Care 2005:9:566-72.

135. Bark BP, Persson J, Grände PO. Importance of the infusion rate for the plasma expanding effect of 5\% albumin, 6\% HES 130/0.4, 4\% gelatin, and $0.9 \% \mathrm{NaCl}$ in the septic rat. Crit Care Med. 2013;41:857-66. 
136. Ishihara $\mathrm{H}$. Impact of fluid infusion rate on restoring plasma volume in sepsis. Crit Care Med. 2013;41:931-2.

137. Kastrup M, Markewitz A, Spies C, Carl M, Erb J, Grosse J, et al. Current practice of hemodynamic monitoring and vasopressor and inotropic therapy in post-operative cardiac surgery patients in Germany: results from a postal survey. Acta Anaesthesiol Scand. 2007;51:347-58.

138. Monnet X, Teboul J-L. Volume responsiveness. Curr Opinion Crit Care. 2007;13:549-53.

139. Marik PE, Baram M, Vahid B. Does central venous pressure predict fluid responsiveness? A systematic review of the literature and the tale of seven mares. Chest. 2008;134:172-8.

140. Marik PE, Cavallazzi R. Does the central venous pressure predict fluid responsiveness? An updated meta-analysis and a plea for some common sense. Crit Care Med. 2013;41:1774-81.

141. Tavernier B, Makhotine O, Lebuffe G, Dupont J, Scherpereel P. Systolic pressure variation as a guide to fluid therapy in patients with sepsisinduced hypotension. Anesthesiology. 1998;89:1313-21.

142. Perel A. Assessing fluid responsiveness by the systolic pressure variation in mechanically ventilated patients. Anesthesiology. 1998;89:1309-10.

143. Shoemaker WC, Appel P, Bland R. Use of physiologic monitoring to predict outcome and to assist in clinical decisions in critically ill postoperative patients. Am J Surg. 1983;146:43-50.

144. Kirov MY, Kuzkov W, Molnar Z. Perioperative haemodynamic therapy. Curr Opin Crit Care. 2010;16:384-92.

145. Wilms H, Mittal A, Haydock MD, van den Heever M, Devaud M, Windsor JA A systematic review of goal directed fluid therapy: rating of evidence for goals and monitoring methods. J Crit Care. 2014;29:204-9.

146. Cherpanath TGV, Geerts BF, Lagrand WK, Schultz MJ, Groeneveld ABJ. Basic concepts of fluid responsiveness. Neth Hearth J. 2013;21:530-6.

147. Cecconi M, Parsons KA, Rodhes A. What is a fluid challenge? Curr Opin Crit Care. 2011;17:290-5.

148. Marik PE, Monnet X, Teboul JL. Hemodynamic parameters to guide fluid therapy. Ann Crit Care. 2011;1:1.

149. Norberg A, Hahn RG, Li H, Olsson J, Prough DS, Børsheim E, et al. Population volume kinetics predicts retention of $0.9 \%$ saline infused in awake and isoflurane-anesthetized volunteers. Anesthesiology. 2007;107:24-32.

150. Curry FR. Atrial natriuretic peptide: an essential physiological regulator of transvascular fluid, protein transport, and plasma volume. J Clin Invest. 2005;115:1458-61.

151. Guyton AC, Hall JE. Textbook of medical physiology. 9th ed. Philadelphia: W. B. Sauders; 1996. p. 123-8.

152. Convertino VA. Blood volume response to physical activity and inactivity. Am J Med Sci. 2007;334:72-9.

153. lijima T, Iwao Y, Sankawa H. Circulating blood volume measured by pulse dye-densitometry: comparison with 1311-HAS analysis. Anesthesiology. 1998;89:1329-35.

154. lijima T, Brandstrup B, Rodhe $P$, Andrijauskas A, Svensen $\mathrm{CH}$. The maintenance and monitoring of perioperative blood volume. Perioper Med. 2013;2:9.

155. Jacob M, Chappell D, Rehm M. The "third space" - fact or fiction? Best Pract Res Clin Anaesthesiol. 2009;23:145-57.

156. Lamke LO, Nilsson GE, Reithner HL. Water loss by evaporation from the abdominal cavity during surgery. Acta Chir Scand. 1977;143:279-84.

157. Jackson R, Reid JA, Thorburn J. Volume preloading is not essential to prevent spinal-induced hypotension at caesarean section. Br J Anaesth. 1995;75:262-5

158. Maharaj CH, Kallam SR, Malik A, Hassett P, Grady D, Laffey JG. Preoperative intravenous fluid therapy decreases postoperative nausea and pain in high risk patients. Anesth Analg. 2005;100:675-82.

159. Lambert KG, Wakim JH, Lambert NE. Preoperative fluid bolus and reduction of postoperative nausea and vomiting in patients undergoing laparoscopic gynecologic surgery. AANAJ. 2009;77:110-4.
160. Holte K, Klarskov B, Christensen DS, Lund C, Nielsen KG, Bie P, et al. Liberal versus restrictive fluid administration to improve recovery after laparoscopic cholecystectomy: a randomized, double-blind study. Ann Surg. 2004;240:892-9.

161. Tatara T, Nagao Y, Tashiro C. The effect of duration of surgery on fluid balance during abdominal surgery: a mathematical model. Anesth Analg. 2009;109:211-6.

162. Fantone JC, Ward PA. Inflammation. In: Rubin E, Farber $J$, editors. Pathology. 3rd ed. Philadelphia: Lippincott-Raven Publishers; 1999. p. 37-75.

\section{Submit your next manuscript to BioMed Central and take full advantage of:}

- Convenient online submission

- Thorough peer review

- No space constraints or color figure charges

- Immediate publication on acceptance

- Inclusion in PubMed, CAS, Scopus and Google Scholar

- Research which is freely available for redistribution 